\title{
The role of snow cover affecting boreal-arctic soil freeze-thaw and carbon dynamics
}

\author{
Y. Yi ${ }^{1}$, J. S. Kimball ${ }^{1}$, M. A. Rawlins ${ }^{2}$, M. Moghaddam ${ }^{3}$, and E. S. Euskirchen ${ }^{4}$ \\ ${ }^{1}$ Numerical Terradynamic Simulation Group (NTSG), College of Forestry and Conservation, The University of Montana, \\ Missoula, MT 59812, USA \\ ${ }^{2}$ Department of Geosciences, University of Massachusetts, Amherst, MA, USA \\ ${ }^{3}$ Department of Electrical Engineering, University of Southern California, Los Angeles, CA, USA \\ ${ }^{4}$ Institute of Arctic Biology, University of Alaska Fairbanks, Fairbanks, AK, USA \\ Correspondence to: Y. Yi (yonghong.yi@ntsg.umt.edu)
}

Received: 15 June 2015 - Published in Biogeosciences Discuss.: 16 July 2015

Revised: 1 October 2015 - Accepted: 2 October 2015 - Published: 13 October 2015

\begin{abstract}
Northern Hemisphere permafrost affected land areas contain about twice as much carbon as the global atmosphere. This vast carbon pool is vulnerable to accelerated losses through mobilization and decomposition under projected global warming. Satellite data records spanning the past 3 decades indicate widespread reductions $(\sim 0.8-$ 1.3 days decade ${ }^{-1}$ ) in the mean annual snow cover extent and frozen-season duration across the pan-Arctic domain, coincident with regional climate warming trends. How the soil carbon pool responds to these changes will have a large impact on regional and global climate. Here, we developed a coupled terrestrial carbon and hydrology model framework with a detailed 1-D soil heat transfer representation to investigate the sensitivity of soil organic carbon stocks and soil decomposition to climate warming and changes in snow cover conditions in the pan-Arctic region over the past 3 decades (19822010). Our results indicate widespread soil active layer deepening across the pan-Arctic, with a mean decadal trend of $6.6 \pm 12.0(\mathrm{SD}) \mathrm{cm}$, corresponding to widespread warming. Warming promotes vegetation growth and soil heterotrophic respiration particularly within surface soil layers $(\leq 0.2 \mathrm{~m})$. The model simulations also show that seasonal snow cover has a large impact on soil temperatures, whereby increases in snow cover promote deeper $(\geq 0.5 \mathrm{~m})$ soil layer warming and soil respiration, while inhibiting soil decomposition from surface $(\leq 0.2 \mathrm{~m})$ soil layers, especially in colder climate zones (mean annual $T \leq-10^{\circ} \mathrm{C}$ ). Our results demonstrate the important control of snow cover on northern soil freeze-thaw and soil carbon decomposition processes and
\end{abstract}

the necessity of considering both warming and a change in precipitation and snow cover regimes in characterizing permafrost soil carbon dynamics.

\section{Introduction}

The northern high latitudes contain about twice as much carbon as the global atmosphere, largely stored in permafrost and seasonally thawed soil active layers (Hugelius et al., 2014). This vast carbon pool is vulnerable to accelerated losses through mobilization and decomposition under regional warming, with potentially large global carbon and climate impacts (Koven et al., 2011; Schaefer et al., 2011; Schuur et al., 2015). The northern high latitudes have experienced a much stronger warming rate than the global average over recent decades (Serreze and Francis, 2006), and this warming trend is projected to continue, along with a general increase in surface precipitation (Solomon et al., 2007). A better understanding of how the northern soil carbon pool responds to these changes is critical to predict climate feedbacks and associated impacts to northern ecosystems.

The potential vulnerability of soil carbon to mobilization and accelerated decomposition with climate warming, particularly in permafrost areas, will largely depend on changes in soil moisture and thermal conditions (Grosse et al., 2011; Schaefer et al., 2011; Schuur et al., 2015). Widespread soil thawing and permafrost degradation in the boreal and Arctic have been reported (e.g., Jorgenson et al., 2006; Romanovsky 
et al., 2010a, b). This has triggered a series of changes in boreal and Arctic ecosystems, including changes in lake and wetland areas (Smith et al., 2005; Watts et al., 2012), tundra shrub cover expansion (Tape et al., 2006; Sturm et al., 2005), thermokarst and other disturbances (Grosse et al., 2011) which are likely having a profound influence on both surface and subsurface hydrology - and biogeochemical cycles. In particular, increases in soil temperature and associated soil thawing potentially expose vast soil organic carbon stocks, formerly stabilized in perennial frozen soils, to mobilization and decomposition, which may promote large positive climate feedbacks (Schaefer et al., 2011; Schuur et al., 2015).

Previous studies have highlighted the importance of both surface air temperature and snow cover conditions affecting the soil thermal regime among many other factors (Stieglitz et al., 2003; Zhang, 2005; Osterkamp, 2007; Lawrence and Slater, 2010; Romanovsky et al., 2010a). Changes in the rate of accumulation, timing, duration, density and amount of snow cover during the winter season play an important role in determining how soil responds to surface warming due to strong insulation effects of snow cover on ground temperature and its role in the surface energy budget (Zhang, 2005). Both surface warming and a changing precipitation regime can modify seasonal snow cover conditions, leading to a nonlinear soil response to warming (Lawrence and Slater, 2010). Increases in winter precipitation and a deepening of the snowpack may enhance soil warming, while a reduced snowpack, due to precipitation decreases or warming-enhanced snow sublimation, may promote soil cooling. Changes in snow cover duration and condition can also alter the amount of energy absorbed by the ground and modify the rate of soil warming (Euskirchen et al., 2007). The Arctic is expected to experience continued warming and precipitation increases under projected climate trends (Solomon et al., 2007); how these climate trends will affect soil moisture and thermal dynamics is a key question affecting potential changes in northern soil carbon dynamics and associated climate feedbacks.

Satellite data records over the past 3 decades (1979-2011) indicate widespread reductions $\left(\sim 0.8-1.3\right.$ days decade $\left.^{-1}\right)$ in mean annual snow cover extent and frozen-season duration across the pan-Arctic domain, coincident with regional warming (Brown and Robinson, 2011; Kim et al., 2012). An earlier onset of spring snowmelt and soil thaw has been observed from both in situ ground and satellite measurements, while the onset of snow cover and soil freezing in the fall show more variable trends (Brown and Robinson, 2011; Kim et al., 2012). More active snowmelt during the snow season, largely in the early snow season, has also been observed from satellite observations of regional snow cover extent and surface freeze-thaw cycles (Kim et al., 2015). On the other hand, snow depth trends in the boreal-Arctic region show large spatial variability. For example, several studies have shown a general snow depth increase in eastern Siberia (e.g., Park et al., 2014) and a decrease in western North America in recent decades (Dyer and Mote, 2006).
The objective of this study is to assess how northern soil thermal and carbon dynamics respond to surface warming and changes in snow cover conditions during the satellite era (since 1979). To that end, we developed a coupled hydrology and carbon model framework with detailed soil heat transfer representation adapted for the pan-Arctic basin and Alaska domain. We used this model to investigate recent climaterelated impacts on soil thermal and carbon dynamics over the past 3 decades (1982-2010). We conducted a sensitivity analysis by running the model with different configurations of surface meteorology inputs to evaluate how soil thermal conditions and soil carbon dynamics respond to changes in air temperature and precipitation during the same period.

\section{Methods}

\subsection{Model description}

A coupled hydrology and carbon model was used to investigate the sensitivity of the soil thermal regime and soil carbon decomposition to changes in surface air temperature and snow cover conditions. The hydrology model accounts for the effects of soil organic layers, changes in surface snow cover properties and soil water phase change on the soil freeze-thaw process in permafrost landscapes (Rawlins et al., 2013). These factors represent important controls on soil thermal dynamics within the active layer (Nicolsky et al., 2007; Lawrence and Slater, 2008, 2010), enabling an improved estimation of subsurface soil temperature and moisture profiles, particularly in permafrost areas, and a representation of essential environmental constraints on soil carbon decomposition.

The hydrology model used for this investigation is an extension of previous efforts regarding large-scale pan-Arctic water balance modeling (PWBM; Rawlins et al., 2003, 2013). Recent updates to the model include an improved simulation of snow or ground and subsurface temperature dynamics using a 1-D heat transfer equation (Rawlins et al., 2013) instead of the empirical thaw depth estimation based on the Stefan solutions used in Rawlins et al. (2003). The updated PWBM model has 23 soil layers down to $60 \mathrm{~m}$ below surface, with increasing layer thickness at depth. Up to five snow layers are used to account for the effects of seasonal snow cover evolution on the ground thermal regime, and changes in seasonal snow density and thermal conductivities are also considered. Other model improvements include accounting for the impact of soil organic carbon content on soil thermal and hydraulic properties (Appendix Sect. A1, Eq. A3); this impact is an important feature of boreal and Arctic soils (Lawrence and Slater, 2008). Further details on the updated hydrology model are provided in Appendix Sect. A1.

A satellite-based terrestrial carbon flux (TCF) model (Yi et al., 2013) was coupled to the hydrology model for this 
investigation. The TCF model uses a light use efficiency algorithm driven by satellite estimates of FPAR (fraction of vegetation canopy intercepted photosynthetically active radiation) to estimate vegetation productivity and litterfall inputs to a soil decomposition model. In the original TCF model, soil carbon stocks and respiration fluxes were estimated using a simplified three-pool soil organic carbon (SOC) decomposition framework with environmental constraints on soil decomposition rates derived from either satellite-estimated surface soil moisture and temperature fields (Kimball et al., 2009) or reanalysis data (Yi et al., 2013). This approach assumes that the major source of soil heterotrophic respiration $\left(R_{\mathrm{h}}\right)$ comes from surface $(\leq 10 \mathrm{~cm})$ litter and surface organic layers. However, the contribution of deeper soils to total $R_{\mathrm{h}}$ may be non-negligible, especially in high-latitude boreal and Arctic tundra landscapes with characteristic carbon-rich soils (Koven et al., 2011; Schuur et al., 2015). Therefore, in this study, we incorporated a more detailed soil decomposition model representing SOC stocks, extending to $3 \mathrm{~m}$ below the surface and representing differences in litterfall and soil organic matter substrate quality within the soil profile (Thornton et al., 2002). The resulting soil decomposition model used for this study includes three litterfall pools, three SOC pools with relatively fast turnover rates and a deep SOC pool with a slow turnover rate (Fig. S1 in the Supplement). The three litterfall pools were distributed within the top $20 \mathrm{~cm}$ of the soil layers; the three fast SOC pools were distributed within the top $50 \mathrm{~cm}$ of the soil layers, and the deep SOC pool extended from $50 \mathrm{~cm}$ to $3 \mathrm{~m}$ below the surface. Substantial SOC may be stored in permafrost soils below $3 \mathrm{~m}$ depth (Hugelius et al., 2014) and may potentially undergo mobilization with continued warming. However, this contribution to total land-atmosphere carbon $\left(\mathrm{CO}_{2}\right)$ exchange was assumed negligible for the recent historical period examined (Schaefer et al., 2011) and was not considered in this study. Further details on the carbon model used in this study are provided in Appendix Sect. A2.

\subsection{Data sets}

The modeling domain for this investigation encompasses the pan-Arctic drainage basin and Alaska, representing a total land area extent of approximately 24.95 million $\mathrm{km}^{2}$. The model was run at a $25 \mathrm{~km}$ Northern Hemisphere Equal-Area Scalable Earth Grid (EASE-Grid) spatial resolution and daily time step from 1979 to 2010. Further details on the model validation data sets and inputs used for this study are provided below.

\subsubsection{In situ data}

In situ measurements from 20 eddy covariance (EC) tower sites across the pan-Arctic domain were obtained from the La Thuile FLUXNET data set (Baldocchi, 2008) and were used to evaluate the model-simulated daily carbon fluxes and soil temperature and moisture fields (Supplement Table S1). These tower sites represent major vegetation community types across the study domain and have at least 1 year of observations available. For validation, the model was driven using tower-observed meteorology. The tower daily carbon flux observations are derived from half-hourly EC $\mathrm{CO}_{2}$ flux measurements that have been processed and aggregated using consistent gap filling and quality control procedures (Baldocchi, 2008). Limited surface $(\leq 15 \mathrm{~cm})$ soil temperature and moisture measurements were also provided at a portion of the tower sites but with unknown soil sampling depths and very few measurements at the tundra sites. Therefore, we selected one boreal forest and one tundra site with detailed in situ measurements (including carbon fluxes, soil temperature and soil moisture) for additional model evaluation (Table 1). The boreal forest site represents a single tower, whereas the tundra site includes three towers, representing three different tundra community types.

The tundra site is located within the Imnavait Creek watershed in the northern foothills of the Brooks Range, Alaska $\left(68^{\circ} 37^{\prime} \mathrm{N}, 149^{\circ} 18^{\prime} \mathrm{W}\right)$, and underlain with continuous permafrost (Euskirchen et al., 2012). Mean annual air temperature and precipitation at the site is $-7.4{ }^{\circ} \mathrm{C}$ and $318 \mathrm{~mm}$ with about 40 and $60 \%$ of annual precipitation occurring as rain and snow, respectively. There are three towers in three different tundra community types, including dry heath, moist acidic tussock and wet sedge tundra. The surface soil organic layer thickness varies from $34.0 \pm 2.4 \mathrm{~cm}$ in wet sedge tundra to $2.3 \pm 0.3 \mathrm{~cm}$ for dry heath tundra. The maximum active layer thaw depth varies from $\sim 40 \mathrm{~cm}$ at the dry heath site to $\sim 70 \mathrm{~cm}$ at the tussock tundra site (Euskirchen et al., 2012). Soil temperature and moisture at $5 \mathrm{~cm}$ depth were measured within each tundra tower footprint. All observations including carbon fluxes and soil temperature and moisture are available from 2008 to 2011.

The boreal forest site used in this study is part of a network of tower EC sites spanning a fire chronosequence in central Manitoba $\left(55^{\circ} 54^{\prime} \mathrm{N}, 98^{\circ} 31^{\prime} \mathrm{W}\right)$ at various stages of succession following large stand replacement fires (Goulden et al., 2011). We chose one of the two oldest chronosequence tower sites burned in 1930 for model validation because this site had more continuous measurements of carbon fluxes and surface meteorology and high-quality data (indicated by the tower metadata) during the observation period (2002-2005). This site is dominated by mature closed-canopy black spruce stands. The mean annual air temperature and precipitation at this site are $-3.2^{\circ} \mathrm{C}$ and $520 \mathrm{~mm}$, respectively. Soil temperatures were measured at the surface $(0 \mathrm{~cm})$ and at multiple $(6,11,16,18,29,41$ and $55 \mathrm{~cm})$ soil depths, while soil moisture was also measured at multiple $(11,18,28,41$ and $55 \mathrm{~cm})$ depths. 
Table 1. Characteristics of two selected tundra and boreal forest tower sites used for model validation. Three tundra types are represented by the tower measurements at Imnavait Creek, Alaska, including dry heath, moist acidic tussock and wet sedge tundra. The boreal forest site encompasses a set of tower eddy covariance (EC) sites and measurements spanning a regional fire chronosequence at various succession stages in central Manitoba, Canada.

\begin{tabular}{lll}
\hline & Tundra & Boreal forest \\
\hline Site & Imnavait Creek, AK & Manitoba, Canada \\
Location (Lat, Long) & $68^{\circ} 37^{\prime} \mathrm{N}, 149^{\circ} 18^{\prime} \mathrm{W}$ & $55^{\circ} 54^{\prime} \mathrm{N}, 98^{\circ} 31^{\prime} \mathrm{W}$ \\
Permafrost & Continuous permafrost & No \\
Observation period & $2008-2011$ & $2002-2005$ \\
Soil temperature measurement depths $(\mathrm{cm})$ & 0,5 & $0,6,11,16,18,29,41,55$ \\
Soil moisture measurement depths $(\mathrm{cm})$ & 5 & $11,18,28,41,55$ \\
\hline
\end{tabular}

\subsubsection{Model inputs}

Primary model drivers include daily surface meteorology and satellite-based normalized difference vegetation index (NDVI) records. Daily average and minimum air temperature, precipitation, wind speed, atmosphere vapor pressure deficit (VPD) and downward solar radiation were obtained from a new version of the WATCH Forcing Data (WFD) applied to the ERA-Interim reanalysis (WFDEI; Weedon et al., 2014). This data set was created by extracting and interpolating the ERA-Interim reanalysis to $0.5^{\circ} \times 0.5^{\circ}$ spatial resolution with sequential elevation correction of surface meteorological variables and monthly bias correction from gridded observations including CRU TS (Climatic Research Unit Time Series; v3.1 and v3.2) and GPCC (Global Precipitation Climatology Centre; v5 and v6) data sets (for precipitation only). The daily WFDEI surface meteorology data is available from 1979 to 2010 and allows more thorough comparisons of hydrological model outputs with other relevant satellite products than the previous WFD data set (Weedon et al., 2014). The third-generation Global Inventory Monitoring and Modelling Studies (GIMMS3g) NDVI data set (Xu et al., 2013) was used to estimate litterfall seasonality and FPAR, as critical inputs to the TCF model (Yi et al., 2013). The GIMMS3g data set was assembled from different NOAA advanced very high-resolution radiometer (AVHRR) sensor records, accounting for various deleterious effects including calibration loss, orbital drift and volcanic eruptions. The NDVI data have a 15-day temporal repeat and $8 \mathrm{~km}$ spatial resolution, extending from 1982 to 2010 . For the model simulations, both WFDEI and GIMMS3g forcing data sets were regridded to a consistent $25 \mathrm{~km}$ EASE-Grid format and the bimonthly GIMMS3g data was interpolated to a daily time step. The NDVI data from 1982 were used as drivers for model spin-up and simulations prior to the start of the GIMMS3g observation record (i.e., 1979-1981).

Other ancillary model inputs included a merged $8 \mathrm{~km}$ land cover data set (Bi et al., 2013) combining the $500 \mathrm{~m}$ MODIS International Geosphere-Biosphere Programme (IGBP) land cover map (Friedl et al., 2010) and the Circumpolar Arctic Vegetation Map (CAVM; Walker et al., 2005). The CAVM was used to identify tundra vegetation within the circumpolar region as a supplement to the IGBP classification, which does not provide a specific category for tundra and foresttundra transition biome types (Bi et al., 2013). The dominant land cover type within each $25 \mathrm{~km}$ EASE-Grid cell was chosen based on the merged $8 \mathrm{~km}$ land cover data set and reclassified according to the original PWBM land cover classification (Rawlins et al., 2013; Fig. S2). Tundra, forest-tundra and taiga-boreal biomes account for approximately $70 \%$ of the total pan-Arctic drainage basin area (Fig. S2).

Soil organic carbon inventory data (GSDT, 2000; Hugelius et al., 2014) were used to prescribe the SOC fraction in each model soil layer. The fraction of SOC has a large impact on soil thermal and hydraulic properties and is therefore an important control on characterizing soil freeze-thaw and moisture processes (Lawrence and Slater, 2008; Nicolsky et al., 2007). The IGBP Global Soil Data Task (GSDT, 2000) and the Northern Circumpolar Soil organic Carbon Database (NCSCD; Hugelius et al., 2014) SOC data were distributed through the top 11 model soil layers $(\leq 1.4 \mathrm{~m}$ depth) across the study area following Rawlins et al. (2013) and Lawrence and Slater (2008). The NCSCD data, which provide an updated estimate of SOC in permafrost affected areas, were used to prescribe the SOC fraction for permafrost areas, while the GSDT data were applied to non-permafrost areas. Generally, the organic carbon fraction within the top 5 soil layers ( $\leq 23 \mathrm{~cm}$ depth) is high, with mean values of 53.7 and $39.4 \%$ for the two deeper surface soil layers $(13-23 \mathrm{~cm}$ depth) averaged over the pan-Arctic domain.

\subsection{Model parameterization}

A dynamic litterfall allocation scheme based on satellite NDVI data (Appendix Sect. A2) was used to prescribe the daily litterfall fraction through each annual cycle to account for litterfall seasonality, particularly for deciduous vegetation types (Randerson et al., 1996; White et al., 2000). The GIMMS3g NDVI bimonthly data were first aggregated to a monthly time step and then used to characterize monthly leaf loss and turnover rates of fine roots during the active growth period based on Eq. (A7). The monthly litterfall frac- 
tion was then evenly distributed at a daily time step within each month. This approach generally allocates more litterfall during the latter half of the growing season, while the model simulations show generally more soil heterotrophic respiration during the latter portion of the year (Fig. S3). A comparison of model simulations against tower measurements shows an overall improved net ecosystem exchange (NEE) seasonality relative to a previous TCF model application where litterfall was distributed evenly over the annual cycle (Yi et al., 2013).

\subsection{Model sensitivity analysis}

We conducted a model sensitivity analysis to examine how the estimated soil thermal regime and SOC decomposition respond to changes in surface air temperature and snow conditions over the most recent 3 decades. Three sets of daily model simulations were run by (1) varying air temperature $(T)$ and precipitation ( $P$ ) inputs; (2) varying $T$ inputs alone (temperature sensitivity analysis), and (3) varying $P$ inputs alone (precipitation sensitivity analysis). Daily mean $T$ (including daily mean and minimum temperature) and $P$ climatology was first derived from the initial 3-year (1979-1981) WFDEI meteorological record and used in the model sensitivity runs. The daily climatology, based on 3-year (19791981) meteorological records rather than a single year (i.e., 1979), was used to minimize effects from characteristically large climate fluctuations in the northern high latitudes. For precipitation, we first created a monthly climatology from the daily record (1979-1981) and then scaled the daily WFDEI precipitation by maintaining the monthly climatology value (Lawrence and Slater, 2010):

$P^{\prime}(y, m, d)=\frac{\overline{P(m)}}{P(y, m)} P(y, m, d)$,

where $y, m$ and $d$ represent a particular year, month and day; $\overline{P(m)}$ is the precipitation monthly climatology averaged from 1979 to 1981 and $P(y, m)$ is the monthly total precipitation for a particular year and month; $P(y, m, d)$ and $P^{\prime}(y, m, d)$ are the original and scaled daily precipitation, respectively, for a particular year, month and day. Due to a relatively short record (i.e., 1979-1981) and large variability in northern latitude precipitation, the ratio of $\frac{\overline{P(m)}}{P(y, m)}$ may be too large for a particular month with very low precipitation rates. In this case, the daily precipitation was not adjusted to avoid unreasonable estimates. We then ran the model with different configurations of the daily surface meteorology data sets. Model simulations derived using the dynamic WFDEI daily surface meteorology from 1979 to 2010 (i.e., varying $T$ and $P$ ) were used as the model baseline simulation. For the temperature sensitivity analysis, we ran the model using the dynamic daily WFDEI temperature records from 1979 to 2010 but holding $P$ as the climatology value from 1979 to 1981. For the precipitation sensitivity analysis, we ran the model using the dynamic daily WFDEI precipitation records but with the $T$ daily climatology. Since VPD is dependent on air temperature, we also created a daily VPD climatology (1979-1981) as an additional input to the carbon model, assuming negligible changes in relative humidity during the study period for the precipitation sensitivity analysis. There was no significant trend in solar radiation during the study period; we therefore used the historical (i.e., 1979-2010) solar radiation data for the three sets of simulations.

The model was initialized using a two-step process prior to the three sets of simulations. The model was first spun-up using the daily surface climatology (1979-1981) including $T$, VPD, and $P$ for 50 years to bring the top $3 \mathrm{~m}$ soil temperature into dynamic equilibrium; the model was then run using the same climatology and simulated soil temperature and moisture fields over several thousand years to bring the SOC pools to equilibrium.

We mainly used correlation analysis to evaluate the climatic controls on simulated soil temperature and carbon fluxes. The outputs from the model baseline simulations (i.e., varying $T$ and $P$ ) from 1982 to 2010 were used for this analysis. The period from 1979 to 1981 was excluded in order to reduce the impact of the spin-up process on model simulations. We first calculated the correlation coefficients between the time series of each climate variable and modeled soil temperature or carbon fluxes at each grid cell from 1982 to 2010. The resulting correlation coefficients were then averaged for each climate zone classified using the annual mean air temperature (1982-2010) and binned into $2.5^{\circ} \mathrm{C}$ intervals. The climate variables used in the correlation analysis included air temperature, snow water equivalent (SWE) and snow cover extent (SCE). The model did not simulate SCE directly, and the SCE was estimated using the following equation:

$\mathrm{SCE}=\frac{\mathrm{SNOWD}}{0.1+\mathrm{SNOWD}}$,

where SNOWD is the simulated snow depth (m), and the surface roughness was set as $0.1 \mathrm{~m}$ (Lawrence and Slater, 2010).

\section{Results}

\subsection{Model validation}

The model simulations were generally consistent with observed daily carbon fluxes from the 20 EC tower sites across the pan-Arctic domain (Table 2), with mean $\mathrm{R}$ values of $0.84 \pm 0.11$ (SD) for gross primary productivity (GPP) and $0.63 \pm 0.17$ for NEE, and mean RMSE differences of $1.44 \pm 0.50 \mathrm{~g} \mathrm{C} \mathrm{m}^{-2} \mathrm{~d}^{-1}$ for GPP and $1.04 \pm 0.36 \mathrm{~g}$ $\mathrm{C} \mathrm{m}^{-2} \mathrm{~d}^{-1}$ for NEE. The model results showed relatively large discrepancies with the tower-based carbon fluxes for tundra sites; however, large uncertainties are associated with the tower measurements in tundra areas due to the characteristically harsh environment and extensive missing data. The simulated temperature and moisture fields also capture 
Table 2. Coefficient of determination $\left(R^{2}\right)$ and root mean square error (RMSE) differences between model-simulated daily carbon fluxes and in situ tower EC measurement-based observations across the study area. The mean of tower-observed daily GPP flux is also shown. The uncertainty of the estimates including mean, $R^{2}$ and RMSE values was indicated as a standard deviation when there were multiple sites represented for each plant functional type.

\begin{tabular}{lrrrrrr}
\hline & \multicolumn{3}{c}{ GPP } & \multicolumn{2}{c}{ NEE } \\
\cline { 3 - 7 } PFT & Tower sites & $\begin{array}{r}\text { Mean } \\
\left(\mathrm{g} \mathrm{C} \mathrm{m}^{-2} \mathrm{~d}^{-1}\right)\end{array}$ & $R^{2}$ & $\begin{array}{r}\text { RMSE } \\
\left(\mathrm{g} \mathrm{C} \mathrm{m}^{-2} \mathrm{~d}^{-1}\right)\end{array}$ & $R^{2}$ & $\begin{array}{r}\text { RMSE } \\
\left(\mathrm{g} \mathrm{C} \mathrm{m}^{-2} \mathrm{~d}^{-1}\right)\end{array}$ \\
\hline ENF & 12 & $2.18 \pm 1.23$ & $0.70 \pm 0.17$ & $1.46 \pm 0.59$ & $0.34 \pm 0.15$ & $1.06 \pm 0.40$ \\
DBF & 2 & $2.11 \pm 0.96$ & $0.82 \pm 0.02$ & $1.31 \pm 0.60$ & $0.59 \pm 0.04$ & $1.29 \pm 0.39$ \\
MXF & 3 & $1.99 \pm 1.02$ & $0.77 \pm 0.03$ & $1.46 \pm 0.45$ & $0.58 \pm 0.11$ & $1.00 \pm 0.29$ \\
GRS & 1 & 1.87 & 0.92 & 1.38 & 0.89 & 1.12 \\
WET & 1 & 0.77 & 0.83 & 1.23 & 0.71 & 0.75 \\
Tundra & 1 & 0.39 & 0.62 & 1.76 & 0.38 & 0.66 \\
\hline
\end{tabular}

PFT (plant functional type): evergreen needleleaf forest; DBF: deciduous broadleaf forest; MXF: mixed forest; GRS: grassland; WET: wetland.

the seasonality of the in situ surface $(\leq 15 \mathrm{~cm})$ soil measurements representing variable soil depths (not shown), despite large uncertainties in the surface meteorology inputs (particularly precipitation or snowfall) and soil parameters, including the definition of texture and peat fraction within the soil profile. Additional assessment of the model simulations was conducted using detailed in situ measurements at selected tundra and boreal forest validation sites (Table 1) as summarized below.

The model simulations compared favorably with in situ measurements at the tundra validation sites for surface soil temperature $\left(R=0.93, \mathrm{RMSE}=3.12^{\circ} \mathrm{C}\right)$ and carbon fluxes, including GPP $\left(R=0.72\right.$, RMSE $\left.=0.76 \mathrm{~g} \mathrm{C} \mathrm{m}^{-2} \mathrm{~d}^{-1}\right)$ and NEE $\left(R=0.79, \operatorname{RMSE}=0.50 \mathrm{~g} \mathrm{C} \mathrm{m}^{-2} \mathrm{~d}^{-1}\right)$ but had a relatively larger discrepancy during the winter when the model showed lower values of NEE (e.g., less $\mathrm{CO}_{2}$ emissions) than the measurements (December to February, DJF; Fig. 1). The simulated maximum soil thaw depth $(\sim 50 \mathrm{~cm}$ averaged from 2008 to 2011) was also consistent with site measurements, ranging from 40 to $70 \mathrm{~cm}$ at three locations within the tundra validation site (Euskirchen et al., 2012). An apparent cold bias ranging from -2 to $-5{ }^{\circ} \mathrm{C}$ in the simulated soil temperature during the fall and winter period of 2009 and 2010 (Fig. 1a) reflects lower model-simulated snow depth and associated reductions in thermal buffering between the atmosphere and underlying soil layers. This cold bias in the simulated soil temperatures results in early freezing of simulated soil water content (Fig. S4). Compared with the tower observations, the simulated daily surface soil temperatures generally show large temporal variations, particularly during the summer (June to August, JJA). There were also considerable differences among in situ soil temperatures at the different tundra sites. Summer (JJA) soil temperature at the wet sedge tundra location was generally lower than for the other tundra vegetation types, which may reflect higher soil water content and specific heat capacity and greater latent heat loss from evapotranspiration, leading to slower soil warming at this site. Overall, the model simulations compare well with the tower-observed carbon fluxes during the growing season but significantly underestimate NEE and soil respiration during the dormant season. Model underestimation of soil respiration during the dormant season may reflect less liquid soil water represented by the model under frozen $\left(<0^{\circ} \mathrm{C}\right)$ temperatures than the tower measurements (Fig. S4) as well as a lack of model representation of wind-induced $\mathrm{CO}_{2}$ exchange between the atmosphere and surface snowpack (Lüers et al., 2014). The model generally shows earlier seasonal onset and offset of photosynthesis relative to the in situ measurements, while partitioning of the tower NEE measurements during the shoulder season may be subject to large uncertainties under partial snow cover conditions (Euskirchen et al., 2012).

The model simulations also compared favorably against observations at the boreal forest validation sites (Fig. 2), capturing observed seasonality in soil temperatures $\left(R>0.95\right.$, RMSE $\left.<2.00^{\circ} \mathrm{C}\right)$ at different soil depths and daily variations in tower-observed carbon fluxes for GPP $\left(R=0.89, \mathrm{RMSE}=1.24 \mathrm{~g} \mathrm{C} \mathrm{m}^{-2} \mathrm{~d}^{-1}\right)$ and NEE $(R=0.73$, RMSE $\left.=0.65 \mathrm{~g} \mathrm{C} \mathrm{m}^{-2} \mathrm{~d}^{-1}\right)$. Similar to the tundra sites, snow depth also has a large impact on simulated soil temperatures at the boreal forest sites but is subject to large uncertainties from both model snowfall inputs and forest canopy snow interception processes. The timing of simulated thaw and freeze of soil water at different depths is generally consistent with the tower measurements, with later seasonal thawing and freezing occurring in deeper soils (Fig. S5). The tower site soil moisture measurements show larger variability than the model simulations during the growing season and likely reflect differences in the model parameterization of surface moss or peat and mineral soil hydraulic conductivities relative to local site conditions. The model-simulated NEE fluxes during the non-growing season stem mainly from soil heterotrophic respiration and 


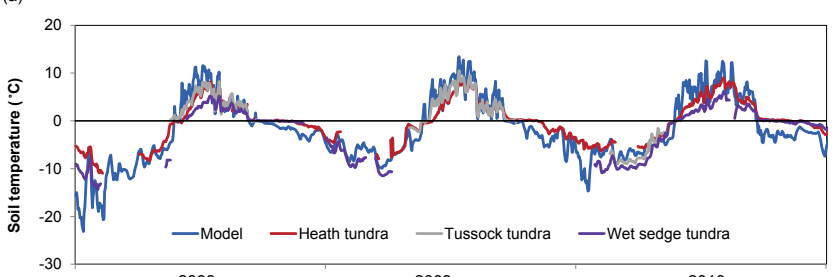

(b)

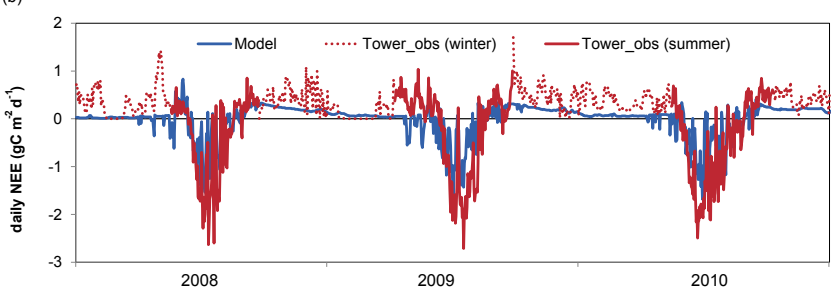

(c)

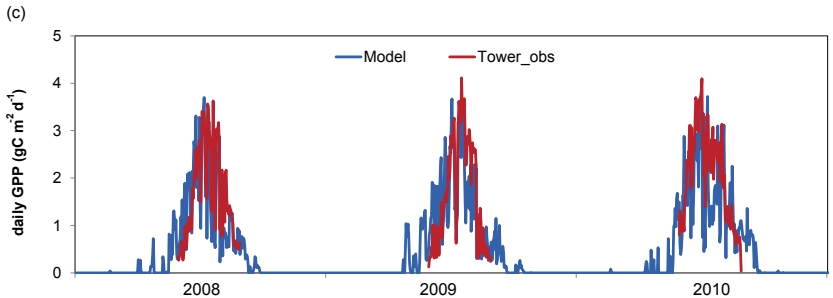

Figure 1. Comparisons of model-simulated (a) surface soil temperature ( $\sim 5 \mathrm{~cm}$ depth) and carbon fluxes (b: NEE; $\mathbf{c}$ : GPP) and tower measurements at the Imnavait Creek, Alaska, tundra sites over a 3year (2008-2010) daily record. The tower-observed carbon fluxes were averaged across three tundra community types, including dry heath, moist acidic tussock and wet sedge tundra except for the NEE measurements during the winter. NEE measurements were not collected at the tussock tundra site during the winter; therefore, the winter NEE measurements were averaged for the dry heath and wet sedge tundra sites only.

are largely consistent with the in situ tower observations, generally diminishing towards the end of the year and then gradually recovering with soil warming toward the onset of the growing season. Both the model and in situ tower NEE fluxes show large temporal variations during the growing season, largely due to GPP reductions caused by high vapor pressure deficits or water stress.

The model-simulated SCE was generally consistent with satellite-observation-based global climate data records documenting weekly SCE changes (Brown and Robinson, 2011; Fig. 3). The model simulations show a similar mean seasonal cycle as the satellite observations, with spring snowmelt mostly occurring from April to May and fall onset of seasonal snow cover occurring in October over the 1982 to 2010 record (Fig. 3a). The model-simulated SCE shows consistent changes with the satellite observations in spring, indicating realistic simulation of the snow melting process. However, the model generally underestimates SCE in the fall and winter. The model did not directly simulate SCE, which was calculated from simulated snow depth using an empir-

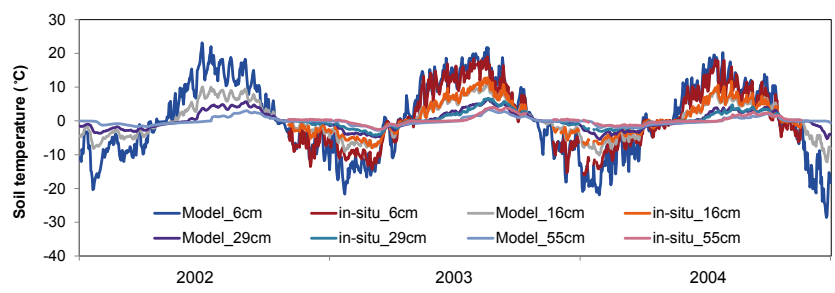

(b)
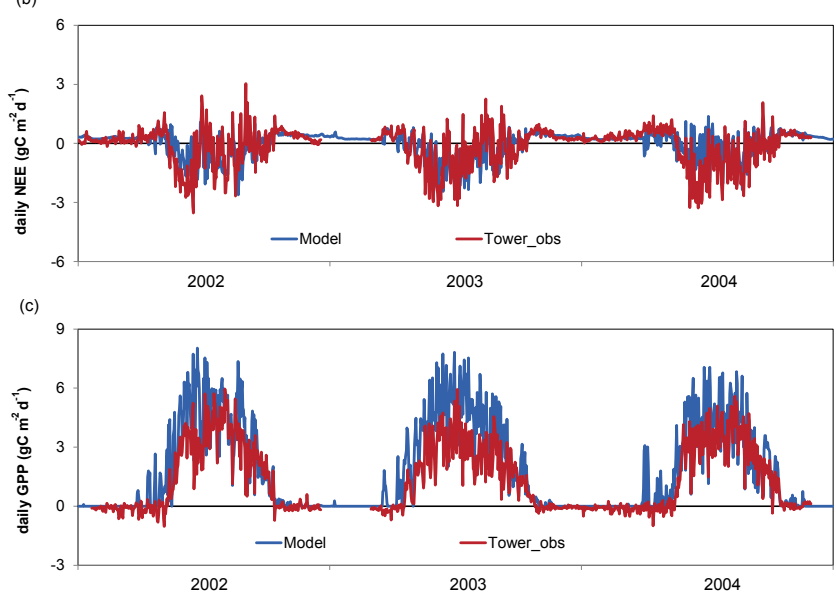

Figure 2. Comparisons of model-simulated (a) soil temperature at different depths $(6,16,29$, and $55 \mathrm{~cm})$ and carbon fluxes (b: NEE; c: GPP) and tower measurements at a mature boreal forest site in Manitoba, Canada, over a 3-year (2002-2004) daily record.

ical equation (Eq. 2). Based on Eq. (2), the modeled SCE will never approach $100 \%$, while the satellite data indicates nearly complete winter snow cover over the study domain. Larger model SCE differences from the satellite observations are expected when the snow cover is relatively shallow and patchy owing to the relatively coarse spatial resolution of both model simulations and satellite observations. Moreover, the satellite SCE data set is presented as a binary classification at a weekly time step, which may not adequately depict transient SCE fluctuations under active surface melting and freezing processes in the fall (Kim et al., 2015).

\subsection{Climatic control on simulated permafrost and soil temperatures}

The simulated permafrost area is generally consistent with reported estimates from previous studies. The simulated mean permafrost area from 1982 to 2010 is approximately 11.3 million $\mathrm{km}^{2}$, which is within the range of observationbased estimates $\left(11.2-13.5\right.$ million $\left.\mathrm{km}^{2}\right)$ of the combined area for continuous (90-100\%) and discontinuous (50$90 \%)$ permafrost extent over the northern polar region $\left(\geq 45^{\circ} \mathrm{N}\right.$ ) (Zhang et al., 2000).

The simulated active layer depth (ALD) shows an overall increasing trend across the pan-Arctic domain over the 1982 to 2010 record (Fig. 4a, b). No strong bias was observed 
(a)
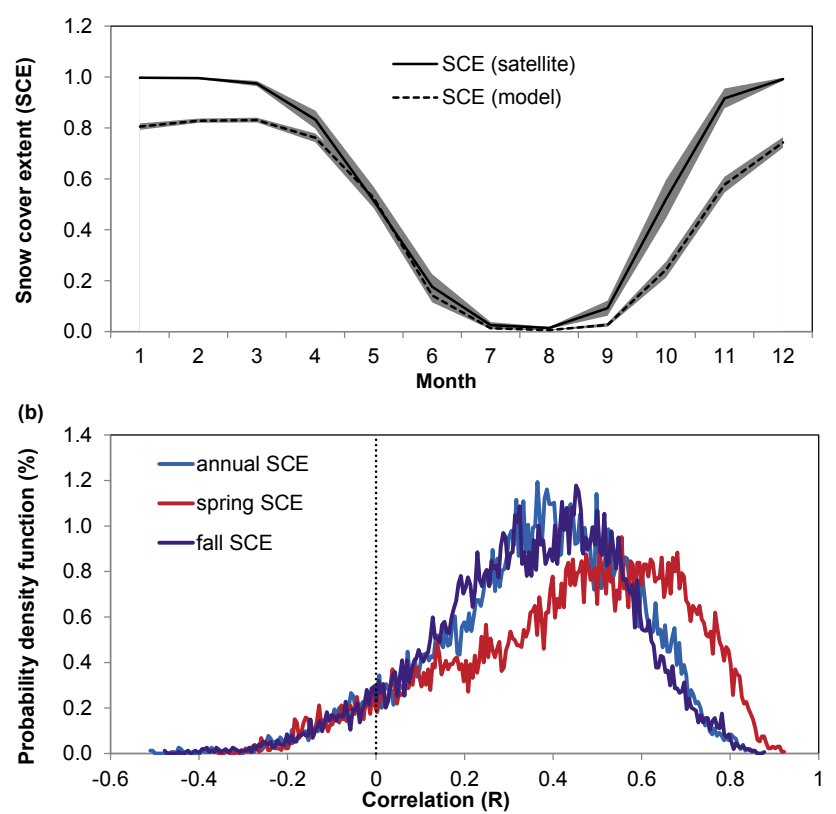

Figure 3. Comparisons of model simulations and satellite-based climate data records (CDR) of snow cover extent (SCE; Brown and Robinson 2011) over the pan-Arctic modeling domain. Panel (a): the seasonal cycle of modeled and satellite-observed SCE; panel (b): the probability density function of the correlation coefficient $(R)$ between modeled and satellite-observed SCE on annual and seasonal timescales (spring: March to May; fall: September to November) from 1982 to 2010 . Gray shading in (a) denotes the temporal standard deviation from the multiyear means for the 1982 to 2010 record.

for the model ALD simulations compared to in situ observations for 53 pan-Arctic sites from the Circumpolar Active Layer Monitoring (CALM) program (Brown et al., 2000); these results showed a mean model bias of $-9.48 \mathrm{~cm}$, representing approximately $16.5 \%$ of the estimated ALD but with low model correspondence $(R=0.31, p<0.1)$ relative to in situ observations (Fig. S6). The discrepancy between modelsimulated ALD results and in situ observations may be partly due to a spatial scale mismatch between the coarse-resolution model simulations and the local CALM site measurements, as well as uncertainties in the reanalysis surface meteorology data used as model forcings (Rawlins et al., 2013). Previous studies have shown large local spatial variations in ALD due to strong surface heterogeneity including microtopography, vegetation and soil moisture conditions (Romanovsky et al., 2010a, b; Mishra and Riley, 2014). Simulated widespread ALD deepening is consistent with generally decreasing snow cover extent in the pan-Arctic region (Fig. 4c). Simulated ALD trends over the 1982-2010 record range from -4.32 to $8.05 \mathrm{~cm} \mathrm{yr}^{-1}$, with a mean value of $0.66 \mathrm{~cm} \mathrm{yr}^{-1}$. A notable model ALD deepening trend occurs in discontinuous permafrost areas with relatively large mean ALD values.

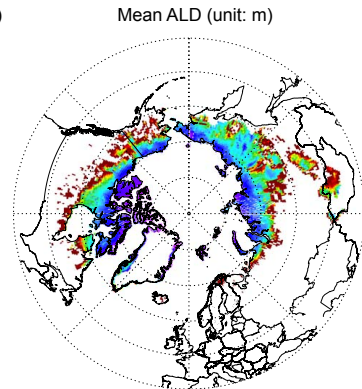

(b) ALD trends (unit: $\mathrm{cm} \mathrm{yr}^{-1}$ )

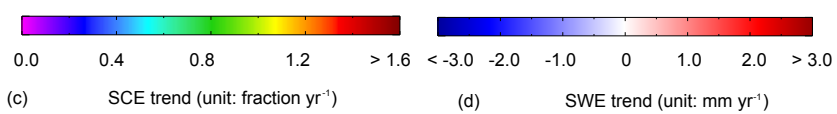

(c)

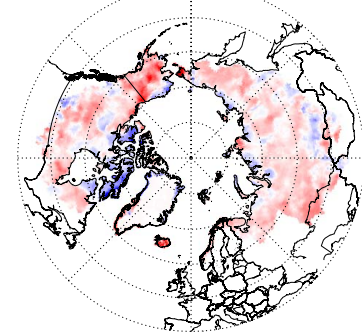

(d)

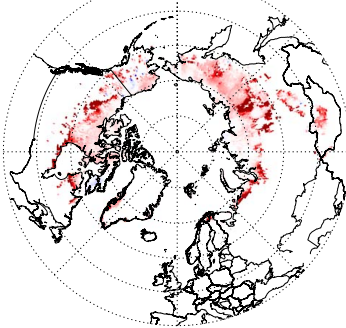

SWE trend (unit: $\mathrm{mm} \mathrm{yr}^{-1}$ )

$<-0.010 \quad-0.005$

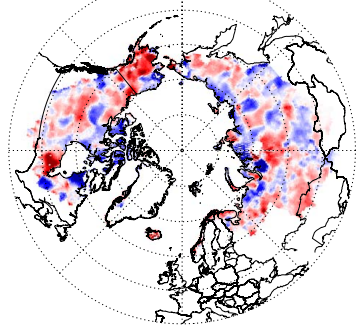

0.005
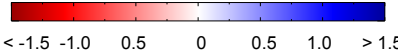

Figure 4. Model-simulated spatial pattern of active layer depth (ALD, a) and estimated trends in ALD (b), snow cover extent (SCE, c) and snow water equivalent (SWE, d) over the pan-Arctic basin and Alaska domain from 1982 to 2010. Areas in white are nonpermafrost areas $(\mathbf{a}, \mathbf{b})$ or outside of the modeling domain.

However, in portions of Alaska, the model simulations indicate slightly decreasing ALD trends across the study period (Fig. 4b), despite a strong reduction in the local snow cover extent (Fig. 4c). This mainly reflects a large decrease in the simulated snowpack (Fig. 4d) due to a decreasing trend in WFDEI precipitation or snowfall data, resulting in less thermal insulation of underlying soil, which may offset warming effects from decreasing snow cover extent.

The regional differences in snow cover effects on modelsimulated ALD can be explained by different climatic controls on warm-season (May to October) soil temperatures. The correlation analysis between climate variables and warm-season soil temperatures (Fig. 5) indicates that surface warming has a dominant control on upper $(<0.5 \mathrm{~m})$ soil temperatures in all climate zones, and also on deeper $(\geq 0.5 \mathrm{~m}$ ) soil temperatures in warmer climate zones (mean annual $T_{\text {air }}>-4{ }^{\circ} \mathrm{C}$ ). A deep snowpack has a strong warming effect on simulated deeper $(\geq 0.5 \mathrm{~m})$ soil temperatures in colder climate zones (mean annual $T_{\text {air }} \leq-4{ }^{\circ} \mathrm{C}$ ) but with limited warming effects on surface soil temperatures across all pan-Arctic climate zones. Correspondingly, the effects of seasonal snow cover duration on model soil temperatures vary across different climate zones and soil depths. In colder climate areas, a longer snow cover duration has a relatively 


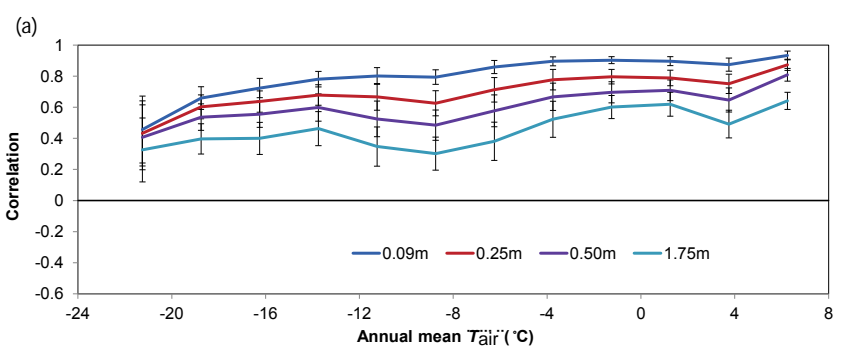

(b)

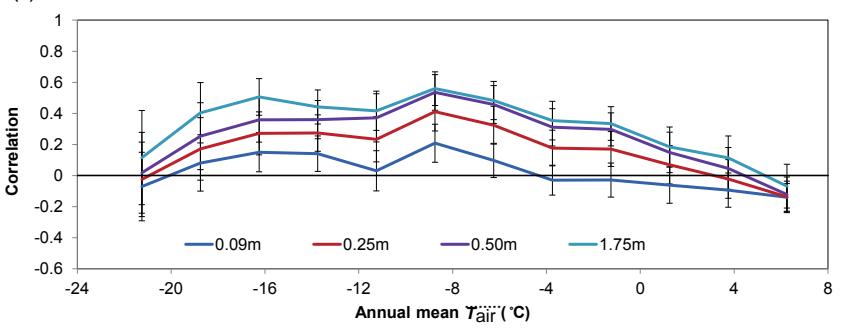

(c)

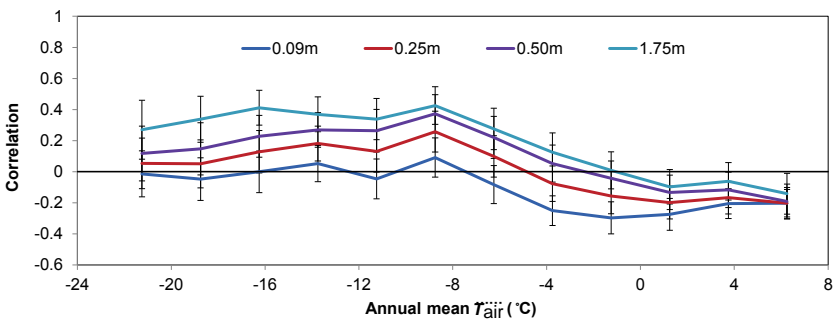

Figure 5. Correlations between climate variables and warm-season (May-October) soil temperature at different soil depths $(0.09,0.25$, 0.50 and $1.75 \mathrm{~m})$. The climate variables used for correlation analysis in each panel are (a) warm-season air temperature $\left(T_{\text {air }}\right)$, (b) preseason snow water equivalent (SWE) and (c) preseason snow cover extent (SCE). The preseason is defined as running from November of one year to April of the next. The correlations were binned into $2.5^{\circ} \mathrm{C}$ intervals. The standard deviation of correlations across each climate zone is shown by the error bars.

strong warming effect on deeper $(\geq 0.5 \mathrm{~m})$ soil temperatures but with negligible warming effects on surface soil layers. In warmer areas, a shorter snow cover season promotes warmer soils, particularly within surface soil layers, due to stronger air and soil thermal coupling. Additional analysis also indicates that earlier snow cover seasonal onset in the fall has a stronger warming effect on modeled soil temperatures in colder climate areas, while earlier offset of seasonal snow cover in the spring has a stronger warming effect on modeled soil temperatures in warmer climate areas.

\subsection{Climatic control on simulated carbon fluxes}

The model simulations indicated that air temperature has an overall dominant control on the two main components of the NEE flux (i.e., net primary productivity, NPP, and $R_{\mathrm{h}}$ ) across all pan-Arctic climate zones, while snow has a larger control on estimated annual NEE fluxes in colder climate areas
(Fig. 6). These results indicate that warming generally promotes vegetation photosynthesis and soil heterotrophic respiration in the pan-Arctic region. However, a reduced positive correlation between NPP and air temperature in warmer climate zones (mean $T_{\text {air }}>0{ }^{\circ} \mathrm{C}$ ) also indicates that warminginduced drought may reduce vegetation productivity to some extent (Kim et al., 2012; Yi et al., 2014). No significant correlation $(p>0.1)$ between NEE and air temperature was observed for most areas (mean $T_{\text {air }} \leq 5^{\circ} \mathrm{C}$ ) due to NEE being a residual between two large fluxes (i.e., NPP and $R_{\mathrm{h}}$ ) with similar temperature responses. A predominantly positive correlation (mean $R=0.32 ; p<0.1$ ) between annual NEE and SWE in colder regions (mean $T_{\text {air }}<-4^{\circ} \mathrm{C}$ ) is mainly due to a strong positive correlation $(R>0.60, p<0.01)$ between SWE and NEE fluxes during the cold season (November to April; Fig. S7). A deeper snowpack promotes warmer soil conditions (Fig. 5b) and associated SOC decomposition and heterotrophic respiration, which contributes significantly to annual NEE, especially in colder climate areas (Zimov et al., 1996). No significant correlation $(p>0.1)$ between annual SCE or SWE and warm-season (MJJASO) carbon fluxes was observed.

While snow cover has a negligible effect on total estimated carbon fluxes during the warm season, it has a strong control on the composition of soil $R_{\mathrm{h}}$ (Fig. 7). An overall, deeper snowpack promotes soil decomposition and respiration from deeper $(\geq 0.5 \mathrm{~m})$ soil layers while inhibiting contributions from surface $(\leq 0.2 \mathrm{~m})$ soil layers, especially in colder climate areas. This response is due to a stronger warming effect of snow cover on deeper soil layers in colder areas (Fig. 5). Comparatively, even though air temperature has a strong control on total warm-season $R_{\mathrm{h}}$ fluxes, it has a limited effect on the contribution of different soil depths to total soil decomposition and respiration except in the warmer climate areas (mean annual $T_{\text {air }}>0{ }^{\circ} \mathrm{C}$ ). In the cold season, a deeper snowpack also promotes soil decomposition in deeper $(>0.2 \mathrm{~m})$ soil layers more than in surface $(0-0.2 \mathrm{~m})$ soil layers.

\subsection{Sensitivity of simulated soil thermal dynamics and soil carbon decomposition to climate variations}

The model sensitivity analysis using different surface meteorology inputs indicated that warming and reduced snow cover extent promoted widespread ALD deepening across the pan-Arctic domain over the 1982 to 2010 record (Fig. 8). In Eurasia, strong winter warming reduced model-simulated SWE and SCE, while increasing winter precipitation generally increased SWE and SCE. In North America, regional trends in winter snowpack and SCE were more variable due to variable trends in winter air temperature and precipitation. Therefore, the resulting model-simulated trends in SWE and SCE based on varying temperature and precipitation inputs showed strong spatial heterogeneity across the pan-Arctic domain. The model sensitivity analysis based on varying temperature inputs alone indicated overall ALD deepening 


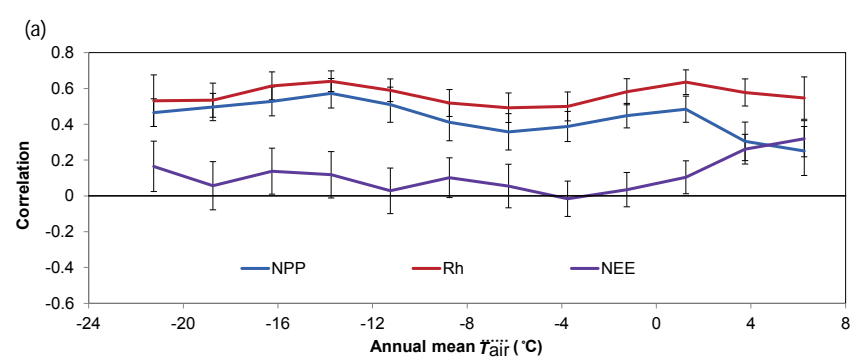

(b)

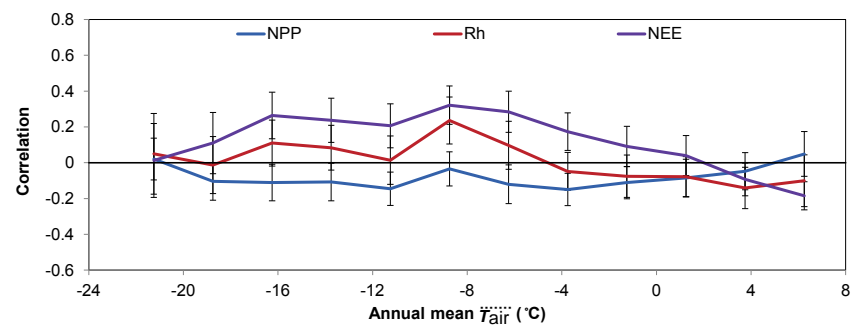

(c)

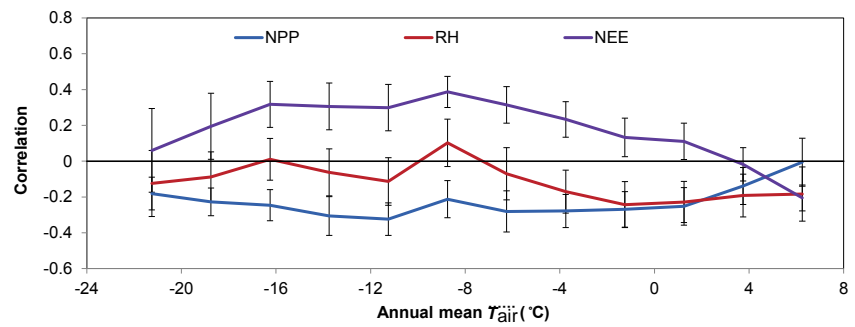

Figure 6. Correlations between annual carbon fluxes and climate variables including (a) annual mean air temperature, (b) annual mean snow water equivalent (SWE), and (c) annual mean snow cover extent (SCE). The annual carbon fluxes include NEE and its two component fluxes (i.e., NPP and soil heterotrophic respiration $R_{\mathrm{h}}$ ). The correlations were binned into $2.5^{\circ} \mathrm{C}$ intervals. The standard deviation of correlations across each climate zone is shown by the error bars.

in permafrost areas, corresponding with widespread warming and reduced SCE. However, the sensitivity analysis based on varying precipitation alone showed more variable trends in the simulated ALD results. Areas with strong decreasing winter precipitation and snowpack trends, such as interior Alaska and eastern Siberia, showed a decreasing ALD trend, attributed to reduced snow insulation effects. The results also indicated that changing air temperature had an overall dominant effect on the simulated ALD trends, though changing precipitation also contributed to ALD changes in some areas.

The model sensitivity analysis indicated that varying precipitation accounts for more of the change in the simulated $R_{\mathrm{h}}$ contribution from different soil depths (i.e., soil $R_{\mathrm{h}}$ fraction; Figs. 9 and 10, and Fig. S8), which is consistent with the above results indicating strong control of snow cover on the soil $R_{\mathrm{h}}$ fraction at different soil depths. The model sensitivity results also indicated that changing air temperature has minimal impact on the simulated soil $R_{\mathrm{h}}$ fraction, while increasing (decreasing) winter snowpack in permafrost areas gener-
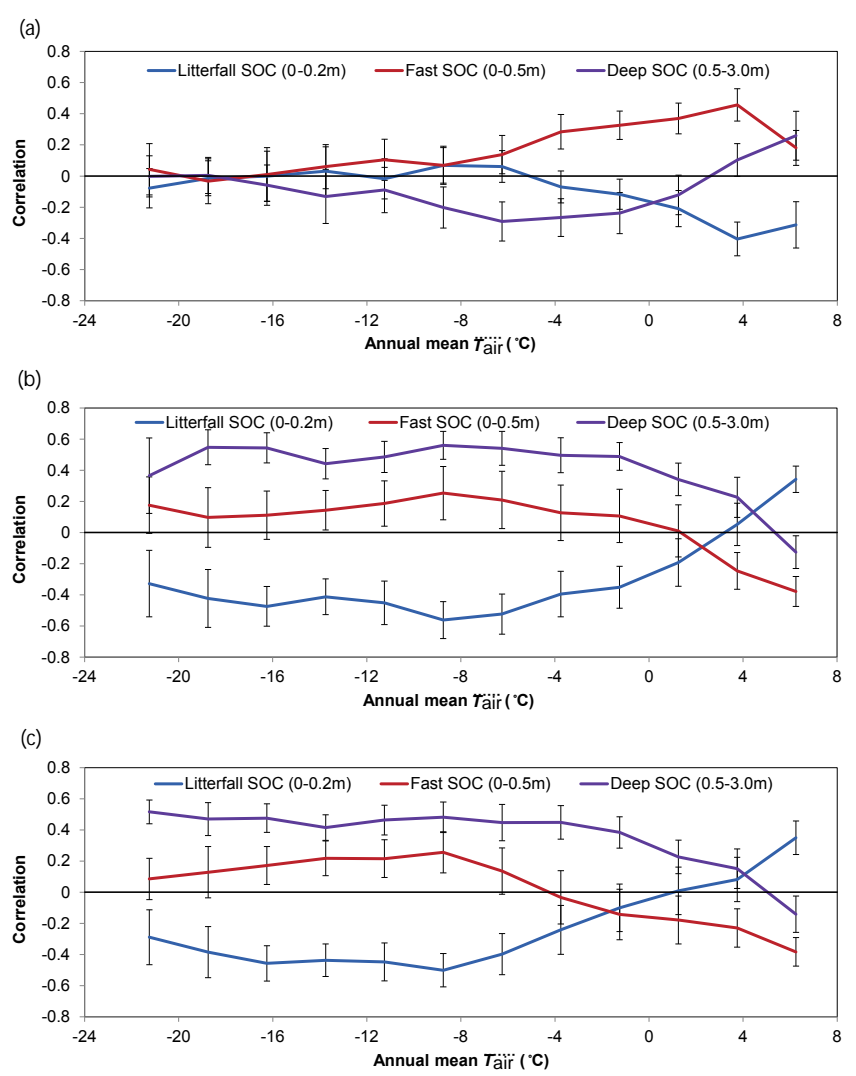

Figure 7. Correlations between climate variables and warm-season (May-October) soil heterotrophic respiration $\left(R_{\mathrm{h}}\right)$ contribution from different soil organic carbon (SOC) pools (i.e., $R_{\mathrm{h}}$ fraction). The climate variables used for the correlation analysis in each panel are (a) warm-season air temperature $\left(T_{\text {air }}\right)$, (b) preseason snow water equivalent (SWE), and (c) preseason snow cover extent (SCE). The correlations were binned into $2.5^{\circ} \mathrm{C}$ intervals. The three litterfall SOC pools were distributed in the top $0.2 \mathrm{~m}$ of the soil layers; the three SOC pools with fast turnover rates were distributed in the top $0.5 \mathrm{~m}$ of the soil layers; the deep SOC pool with slow turnover rates extended from 0.5 to $3 \mathrm{~m}$ below surface. The standard deviation of correlations across each climate zone is shown by the error bars.

ally corresponded to increasing (decreasing) soil $R_{\mathrm{h}}$ fraction from deeper $(>0.5 \mathrm{~m})$ soil layers and decreasing (increasing) soil $R_{\mathrm{h}}$ contributions from surface $(0-0.2 \mathrm{~m})$ soil layers (Fig. 9). This is particularly true in cold climate regions (mean annual $T_{\text {air }}<-10^{\circ} \mathrm{C}$; Fig. 10). The simulated $R_{\mathrm{h}}$ fraction from the deeper soil layers $(0.5-3.0 \mathrm{~m})$ based on model runs using varying precipitation alone did not show significant differences $(p>0.1)$ from model simulations based on varying air temperature and precipitation. However, the simulated soil $R_{\mathrm{h}}$ fraction from both surface $(0-0.2 \mathrm{~m})$ and deeper $(0.5-3.0 \mathrm{~m})$ soil layers based on model runs using varying temperature alone was significantly $(p<0.01)$ different from model simulation results based on varying air temperature and precipitation. Moreover, cold regions (mean 
(a) Varying T \& P

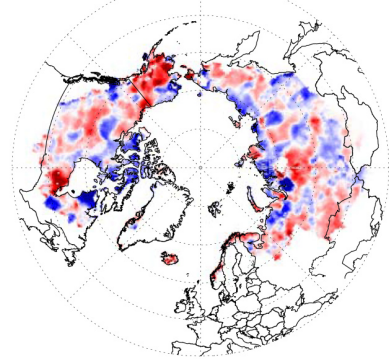

Varying T

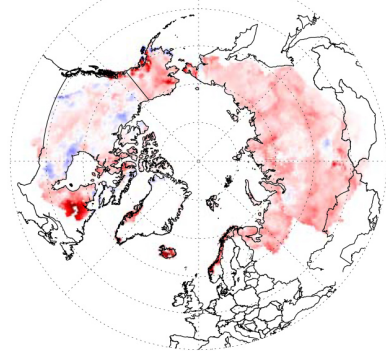

Varying $P$

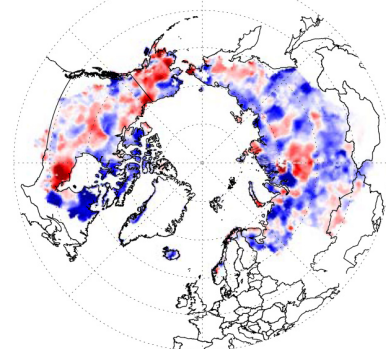

SWE $\left(\mathrm{mm} \mathrm{yr}^{-1}\right)$

(b)
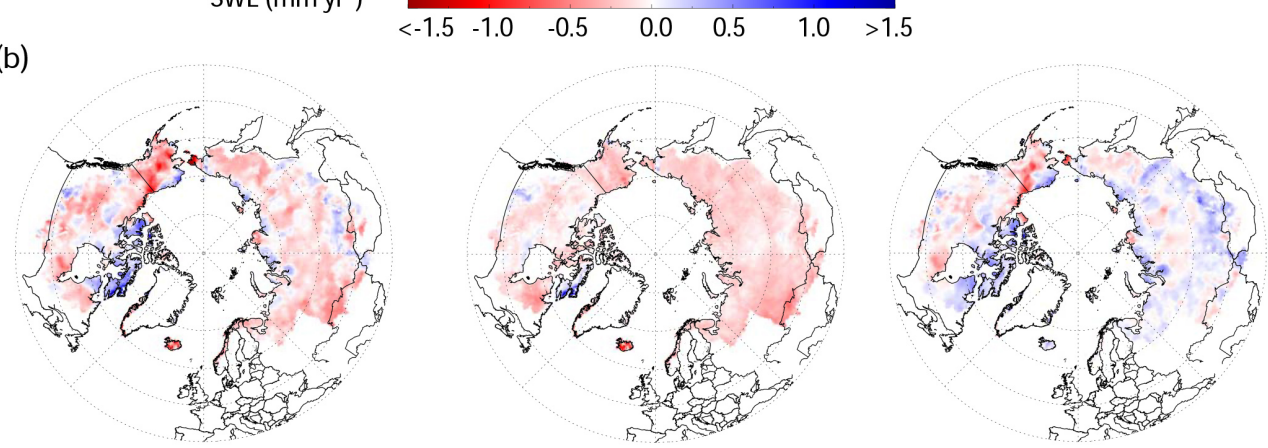

SCE (fraction $\mathrm{yr}^{-1}$ )

$$
\begin{array}{lllll}
<-0.01 & -0.005 & 0.0 & 0.005 & >0.01
\end{array}
$$

(c)
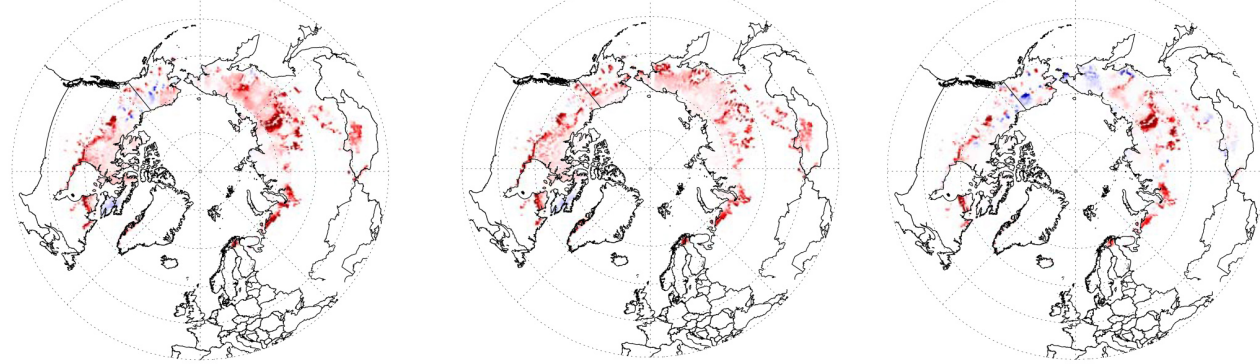

ALD ( $\left.\mathrm{cm} \mathrm{yr}^{-1}\right)$

$$
\begin{array}{lllllll}
<-3.0 & -2.0 & -1.0 & 0.0 & 1.0 & 2.0 & >3.0
\end{array}
$$

Figure 8. Simulated trends of (a) snow water equivalent (SWE), (b) snow cover extent (SCE) and (c) active layer depth (ALD) for the three model sensitivity experiments for the 1982 to 2010 period. For the sensitivity analysis, the model was driven using different surface meteorology data sets. The results based on model runs using varying temperature $(T)$ and precipitation $(P)$ are presented in the left column; the results based on model runs using varying $T$ alone are shown in the middle column; and results based on model runs using varying $P$ alone are shown in the right column.

$T_{\text {air }}<-10^{\circ} \mathrm{C}$ ) showed stronger decreasing trends in the $R_{\mathrm{h}}$ fraction from surface soil layers and increasing soil $R_{\mathrm{h}}$ contributions from deeper soil layers, likely due to increasing winter precipitation and snow cover (Figs. 8 and 9) and consistent with field studies involving snow cover manipulations and associated impacts on soil respiration (e.g., Nowinski et al., 2010).

\section{Discussion}

\subsection{Impact of climate variations on soil active layer properties}

Our results show that recent strong surface warming trends in the pan-Arctic region have promoted widespread soil thawing and ALD deepening (Fig. 8), while changing precipitation and snow depth have had a relatively smaller impact on ALD trends (Figs. 4 and 8). We find a mean increasing ALD trend of $0.66 \pm 1.20 \mathrm{~cm} \mathrm{yr}^{-1}$ across the pan-Arctic re- 
(a)
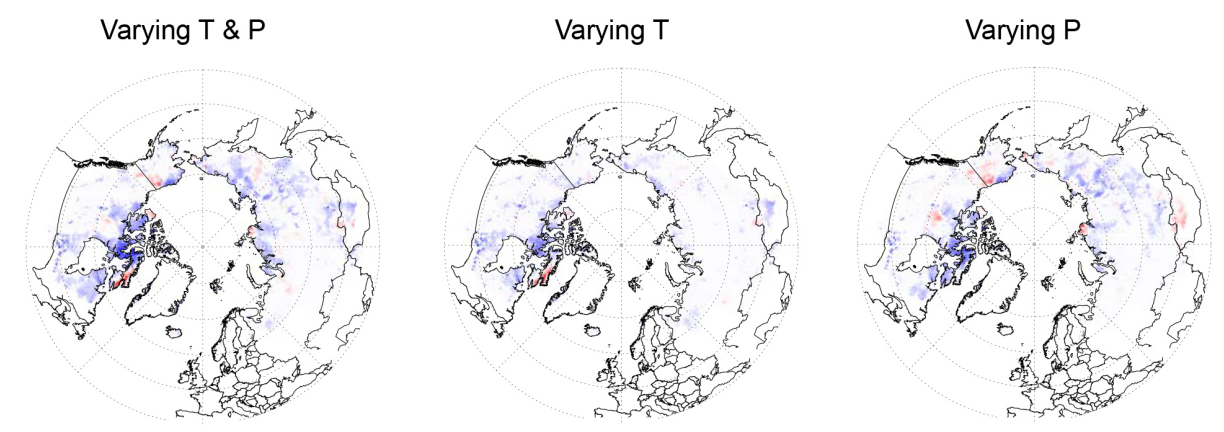

(b)
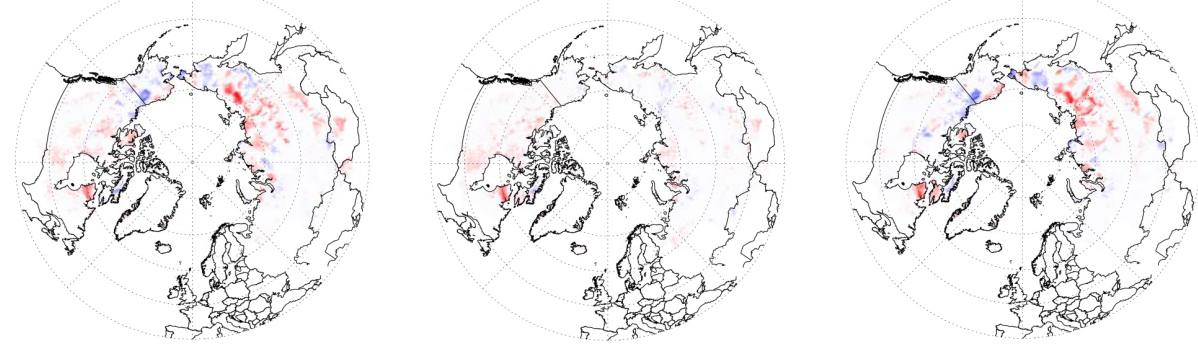

Rh fraction trends $\left(\mathrm{yr}^{-1}\right)$

$\begin{array}{lllll}<-0.006 & -0.003 & 0.0 & 0.003 & >0.006\end{array}$

Figure 9. Similar to Fig. 8 but for simulated trends (unit: $\mathrm{yr}^{-1}$ ) of the warm-season (May-October) soil heterotrophic respiration $\left(R_{\mathrm{h}}\right)$ contribution (i.e., $R_{\mathrm{h}}$ fraction) from (a) surface $(0-0.2 \mathrm{~m})$ and (b) deep $(0.5-3.0 \mathrm{~m})$ soil carbon pools for the three sensitivity experiments using different surface meteorology configurations, i.e., varying temperature $(T)$ and precipitation $(P)$ inputs, from 1982 to 2010.

gion over the past 3 decades, which is similar to values reported in previous studies (Zhang et al., 2005; Romanovsky et al., 2010a), albeit representing different time periods. This overall ALD deepening trend across the pan-Arctic domain corresponds with widespread warming and warming-induced decreases in SCE (Fig. 4c) and increasing non-frozen-season duration (Kim et al., 2012). Our analysis indicates that air temperature has a dominant control on upper $(<0.5 \mathrm{~m})$ soil layer temperatures during the warm-season, with an increasing control in warmer climate zones (Fig. 5a). The model simulations also suggest that most pan-Arctic permafrost areas, especially continuous permafrost areas, have a relatively shallow $(<1 \mathrm{~m})$ active layer (e.g., Fig. 4a). Therefore, rapid warming of the upper soil layers corresponds with general ALD deepening.

Previous studies have also shown that summer air temperature is a primary control on ALD trends, while the relationship between snow cover and ALD is more variable (Zhang et al., 2005; Romanovsky et al., 2010a, b). Our results demonstrate that deeper snowpack conditions promote warming of deep (>0.5 m) soil layers, especially in colder climate areas (Fig. 5b), and this effect exceeds the impact of surface warming on deeper soil layers (e.g., >1 m). Previous studies indicate that changes in snow depth can influence borehole (10-20 m) permafrost temperatures as much as changes in air temperature (Stieglitz et al., 2003; Romanovsky et al., 2010a, b). Regional simulations from the improved Community Land Model (CLM) also indicate that snow state changes can explain $50 \%$ or more of soil temperature trends at $1 \mathrm{~m}$ depth over the recent 50 -year record (Lawrence and Slater, 2010). On the other hand, the impact of changing snow cover duration on soil temperatures may vary across different climate zones (Fig. $5 \mathrm{c}$ ) due to the influence of both air temperature and precipitation or snowfall on snow cover duration. A shorter snow cover season may cool the soil in colder climate zones due to less insulation from cold temperatures but may warm the soil in warmer climate zones by promoting greater atmospheric heat transfer into soils (Lawrence and Slater, 2010; Euskirchen et al., 2007). Our results indicate that recent regional trends toward continued warming, earlier spring snowmelt onset and a shorter snow cover season will likely enhance soil warming and permafrost degradation in relatively warmer (mean annual $T_{\text {air }}>-5^{\circ} \mathrm{C}$ ) regions of the pan-Arctic domain.

\subsection{Impact of climate variations on soil carbon dynamics}

Snow cover is an important control on the annual carbon budget in cold regions (annual mean $T_{\text {air }}<-4{ }^{\circ} \mathrm{C}$; Fig. $6 \mathrm{~b}-\mathrm{c}$ ), even though air temperature has a dominant control on both annual NPP and $R_{\mathrm{h}}$ fluxes across all climate zones (Fig. 6a). Strong snow cover buffering of underlying soil temperatures sustains soil respiration even under very cold winter air tem- 
(a)

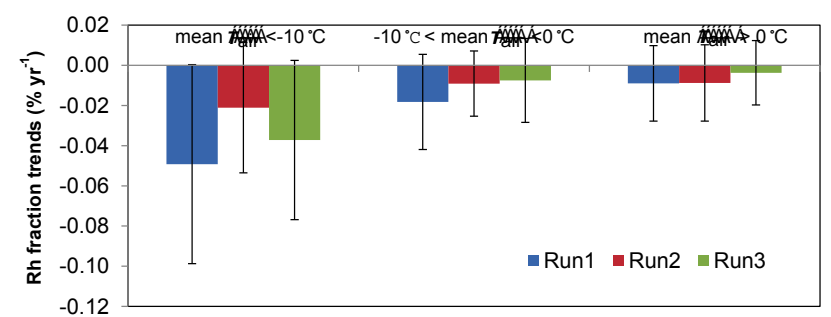

(b)

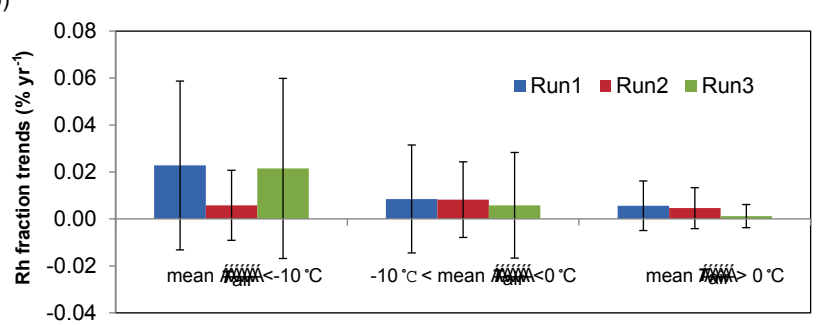

Figure 10. The zonal-average trends of warm-season (MayOctober) soil heterotrophic respiration $\left(R_{\mathrm{h}}\right)$ contribution (i.e., $R_{\mathrm{h}}$ fraction) from (a) surface litterfall $(0-0.2 \mathrm{~m})$ and (b) deep $(0.5-$ $3.0 \mathrm{~m}$ ) soil carbon pools for the three sensitivity experiments from 1982 to 2010 . Run1 indicates model simulations based on varying temperature $(T)$ and precipitation $(P)$ inputs; Run2 indicates model simulations based on varying $T$ inputs alone; and Run3 indicates model simulations based on varying $P$ inputs alone.

peratures, and the resulting winter soil respiration can be a large component of the annual NEE budget (Sullivan et al., 2010). Field experiments have shown that winter soil respiration in tundra areas can offset total net carbon uptake during the growing season and thus switch the ecosystem from a net carbon sink to a carbon source (Zimov et al., 1996; Euskirchen et al., 2012; Lüers et al., 2014). Our results also indicate that cold-season (November-April) $R_{\mathrm{h}}$ accounts for $\sim 25 \%$ of total annual $R_{\mathrm{h}}$ over the entire pan-Arctic domain, while this estimate may be conservative since our model may underestimate soil respiration in tundra areas (Fig. 1b). The model simulations indicate very low $(<5 \%)$ unfrozen water below $\sim-3^{\circ} \mathrm{C}$ at the tundra sites, while previous studies and the tower measurements (Fig. S4) indicate that substantial unfrozen water may remain even under very low soil temperatures (e.g., $\sim-10^{\circ} \mathrm{C}$ ), sustaining soil microbial activities (Romanovsky and Osterkamp, 2000). On the other hand, winter warming may change the depth and structure of insulating snow cover, affecting underlying soil temperatures, which could alter soil $\mathrm{N}$ mineralization rates and soil microbial activities that influence ecological processes during the growing season (Schimel et al., 2004; Sturm et al., 2005; Monson et al., 2006).

Even though air temperature has a dominant control on $R_{\mathrm{h}}$ during the warm season (from May to October), snow cover strongly influences the contribution of different soil depths to total soil decomposition and $R_{\mathrm{h}}$ (Fig. 7). This nonlinear response is due to different controls of surface air temperature and snow cover on soil temperatures at different soil depths (Zhang, 2005; Romanovsky et al., 2010a, b; Lawrence and Slater, 2010). Surface warming during the summer has a dominant control on upper soil layer temperatures $(<0.5 \mathrm{~m}$; Fig. 5a), while a deeper winter snowpack has a persistent warming effect on deeper soil temperatures in colder climate areas (Fig. 5b; Gouttevin et al., 2012). Therefore, surface warming likely promotes more heterotrophic respiration from surface litter and soil layers, while a deeper snowpack promotes soil respiration from deeper soil layers. This is particularly important for soil carbon dynamics in permafrost areas, where a large amount of soil carbon occurs in deep perennial frozen soils (Hugelius et al., 2014). Previous studies including field experiments have primarily focused on the effects of surface warming on permafrost soil carbon decomposition (e.g., Schuur et al., 2007; Koven et al., 2011; Schaefer et al., 2011), while our results show that snow cover may play a larger role than air temperature in influencing deeper soil temperatures and permafrost stability. This is also supported by a recent snow addition experiment in Alaskan tundra areas (Nowinski et al., 2010), which showed that a deeper snow treatment resulted in a larger contribution of deep and old soil carbon decomposition to total soil heterotrophic respiration.

\subsection{Limitations and uncertainties}

Although soil temperature and moisture are the two major environmental controls on soil carbon decomposition, other factors may also influence soil decomposition rates and permafrost carbon feedback potential but are not represented by our modeling study (Hobbie et al., 2000). A number of chemical and biological factors can affect the temperature sensitivity of soil carbon decomposition in northern soils, including enzyme abundance, microbial population size and oxygen availability (Waldrop et al., 2010). Previous studies also show that soil carbon decomposition rates may be depth-dependent. Accounting for vertical changes in soil biogeochemical properties and processes (including the size and substrate quality of the soil active layer and permafrost carbon pool, and the degree of $\mathrm{N}$ mineralization with decomposing permafrost carbon) may have significant impacts on the sign and magnitude of the projected high-latitude carbon response to future warming (Koven et al., 2011, 2015). Finally, changing wintertime soil microclimate will alter the amount and timing of plant-available nutrients $(N)$ in tundra ecosystems and may drive a positive feedback between snow, soil temperature, microbial activity, and plant community composition (Schimel et al., 2004; Sturm et al., 2005).

A number of processes, notably fire disturbance, shrub expansion and thermokarst, are not included in this study but may be important factors affecting regional permafrost and soil carbon dynamics (Grosse et al., 2011; Schuur et al., 2015). A warming climate has been linked with increasing 
boreal-arctic fire activity and severity (Grosse et al., 2011). Fire can change the surface vegetation composition and consume a large portion of the soil organic layer, which can dramatically alter the surface energy balance and soil thermal properties, and cause rapid permafrost degradation (Harden et al. 2006; Jafarov et al., 2013). Both field experiments and satellite measurements indicate a "greening" Arctic with increasing shrub abundance due to climate warming (Tape et al., 2006). Shrub expansion in Arctic tundra can change the snow distribution and surface albedo, affecting the surface energy balance and underlying active layer and permafrost conditions (Sturm et al., 2005). The development of surface water ponding with thermokarst in ice-rich permafrost areas can alter the local surface hydrology, affecting permafrost and soil carbon decomposition (Schuur et al., 2007; Grosse et al., 2011).

Another important feature of the Arctic is strong surface heterogeneity, characterized by widespread lakes, ponds, wetlands and waterlogged soils as a result of both topography and restricted surface drainage due to underlying permafrost. Changes in both surface and subsurface hydrology are tightly coupled with local permafrost conditions and potential carbon and climate feedbacks (Smith et al., 2005; Watts et al., 2012; Yi et al., 2014; Schuur et al., 2015). Current largescale model simulations, including this study, generally operate on the order of tens of kilometers or even larger, and may not adequately represent the effects of surface heterogeneity on simulated permafrost hydrologic processes and soil carbon decomposition processes (Koven et al., 2011; Rawlins et al., 2013; Schuur et al., 2015). For example, most models prescribe a dominant vegetation type or a single value for the organic layer thickness commensurate with the model spatial resolution, which likely introduces large uncertainties to the model-simulated moisture and heat fluxes and thus the permafrost properties. Next generation satellites, including the NASA SMAP (Soil Moisture Active Passive) mission provide for finer-scale (i.e., 3-9 km resolution) monitoring and enhanced (L-band) microwave sensitivity to surface $(\sim<5 \mathrm{~cm})$ soil freeze-thaw and moisture conditions (Entekhabi et al., 2010) and may enable improved regional hydrological and ecological model parameterizations and simulations that more accurately represent active layer conditions. Finer-spatial-scale observations using lower-frequency (such as P-band) synthetic aperture radar (SAR) measurements from airborne sensors such as AirMOSS (Airborne Microwave Observatory of Subcanopy and Subsurface instrument; Tabatabaeenejad et al., 2015) may also provide improved information on sub-grid-scale processes and subsurface soil thermal and moisture profiles, providing critical constraints on model predictions of soil active layer changes and soil carbon and permafrost vulnerability.

\section{Conclusions}

We developed a coupled hydrology and terrestrial carbon flux modeling framework to evaluate the sensitivity of soil thermal and carbon dynamics to snow cover and recent climate variations across the pan-Arctic basin and Alaska during the past 3 decades (1982-2010). Our results indicate that surface warming promotes widespread soil thawing and active layer deepening due to a strong control of surface air temperature on upper $(<0.5 \mathrm{~m})$ soil temperatures during the warm season (from May to October). Recent trends indicating earlier spring snowmelt and shorter seasonal snow cover duration with regional warming (Dyer and Mote, 2006; Brown and Robinson, 2011; Kim et al., 2012) will most likely enhance soil warming in relatively warmer climate zones (mean annual $T_{\text {air }}>-5^{\circ} \mathrm{C}$ ) and promote permafrost degradation in these areas. Even though air temperature has a dominant control on soil decomposition during the warm season, snow cover has a strong control on the contribution of different soil depths to the total soil heterotrophic respiration flux. A deeper snowpack inhibits surface $(<0.2 \mathrm{~m})$ litter and soil organic carbon decomposition but enhances soil decomposition and respiration from the deeper $(>0.5 \mathrm{~m})$ soil carbon pool. This nonlinear relationship between snow cover and soil decomposition is particularly important in permafrost areas, where a large amount of soil carbon is stored in deep perennial frozen soils that are potentially vulnerable to mobilization and accelerated losses from near-term climate change. Our results demonstrate the important control of snow cover in affecting active layer properties and soil carbon decomposition processes across the pan-Arctic and the necessity of considering both warming and a change in precipitation and snow cover regimes in characterizing permafrost soil carbon dynamics. In addition, further improvements in regional assessment and monitoring of precipitation and snow cover across the northern high latitudes are needed to improve the quantification and understanding of linkages between snow and permafrost carbon dynamics. 


\section{Appendix A}

\section{A1 Hydrology model description}

The PWBM model (Rawlins et al., 2013) simulates snow and ground thermal dynamics by solving a 1-D heat transfer equation with phase change (Nicolsky et al., 2007):

$$
\begin{aligned}
& C \frac{\partial}{\partial t} T(z, t)+L \zeta \frac{\partial}{\partial t} \theta(T, z)=\frac{\partial}{\partial z}\left(\lambda \frac{\partial}{\partial z} T(z, t)\right), \\
& z \in\left[z_{\mathrm{s}}, z_{\mathrm{b}}\right],
\end{aligned}
$$

where $T(z, t)$ is the temperature $\left({ }^{\circ} \mathrm{C}\right)$ and $C(T, z)$ and $\lambda(T, z)$ are the volumetric heat capacity $\left(\mathrm{J} \mathrm{m}^{-3} \mathrm{~K}^{-1}\right)$ and thermal conductivity $\left(\mathrm{W} \mathrm{m}^{-1} \mathrm{~K}^{-1}\right)$ of soil, respectively; $L$ is the volumetric latent heat of the fusion of water $\left(\mathrm{J} \mathrm{m}^{-3}\right) ; \zeta$ is the volumetric water content, and $\theta$ is the unfrozen liquid water fraction. The Dirichlet boundary conditions at the snow or ground surface $z_{\mathrm{s}}$, i.e., $T\left(z_{\mathrm{s}}, t\right)=T_{\text {air }}(t)$, and a heat boundary condition at the lower boundary $z_{\mathrm{b}}$, i.e., $\lambda \frac{\partial}{\partial z} T(l, t)=g$, were used to solve the heat equation, where $T_{\text {air }}$ is the observed air temperature and $g$ is the geothermal heat flux $\left(\mathrm{K} \mathrm{m}^{-1}\right)$. The volumetric water content $(\zeta)$ can be obtained by solving the Richard's equation. The unfrozen liquid water fraction $(\theta)$ was estimated empirically as

$\theta= \begin{cases}1 & T \geq T_{*} \\ \left|T_{*}\right|^{b}|T|^{-b} & T<T_{*},\end{cases}$

where the constant $T_{*}$ is the freezing point depression, and $b$ is a dimensionless parameter obtained from unfrozen water curve fitting (Romanovsky and Osterkamp, 2000).

The bulk thermal properties of soil (i.e., $C$ and $\lambda$ ) are a combination of the thermal properties of soil solids, air, and thawed and frozen states of soil water (Rawlins et al., 2013). Particularly, for the soil solids, the volumetric heat capacity $\left(C_{\mathrm{s}}\right)$ and thermal conductivities $\left(\lambda_{\mathrm{s}}\right)$ vary with the fraction of organic carbon of the soil, defined as

$C_{\mathrm{s}}=(1-f) C_{\mathrm{m}}+f C_{\mathrm{o}} ; \quad \lambda_{s}=\lambda_{m}^{1-f} \lambda_{o}^{f}$,

where $f$ is the fraction of organic carbon in the soil, $C_{\mathrm{m}}$ and $C_{\mathrm{o}}$ are the volumetric heat capacities of the mineral and organic soils, respectively, and $\lambda_{m}$ and $\lambda_{o}$ are the thermal conductivities of the mineral and organic soils, respectively.

Up to five snow layers were used to characterize the snowpack dynamics and solve the snow temperature profile, with varying depth for each layer depending on the snow depth. A two-layer snow density model similar to Schaefer et al. (2009) was used to characterize the impact of the bottomdepth hoar layer on the snow thermal conductivity for tundra and taiga, with fixed snow thermal conductivity for this layer. For the upper snow layer, both the snow heat capacity and thermal conductivity vary with snow density. Following Liston et al. (2007), the temporal evolution of the snow density is mainly affected by new snowfall and compaction due to winds:

$\frac{\mathrm{d} \rho_{\mathrm{s}}}{\mathrm{d} t}=0.1 a_{1} U \rho_{\mathrm{s}} e^{\left(-b\left(T_{\mathrm{f}}-T_{\mathrm{s}}\right)\right)} e^{\left(-a_{2} \rho_{\mathrm{s}}\right)}$,

where $\rho_{\mathrm{S}}$ is the snow density $\left(\mathrm{kg} \mathrm{m}^{-3}\right), \mathrm{U}$ represents the wind-speed contribution to the snow density changes with negligible influence for wind speed below $5 \mathrm{~m} \mathrm{~s}^{-1} ; T_{\mathrm{f}}$ and $T_{\mathrm{S}}$ are the freezing and snow temperatures, respectively; $a_{1}$, $a_{2}$ and $b$ are empirical dimensionless parameters. The snow thermal conductivity $\left(\lambda_{\text {snow }}\right)$ is an empirical estimate of snow density based on Sturm et al. (1997):

$\lambda_{\text {snow }}=0.138-1.01 \rho_{\mathrm{s}}+3.233 \rho_{\mathrm{s}}^{2}$.

More details on the numerical solution of the heat transfer equation and the parameterization of the snow model can be found in Rawlins et al. (2013) and Nicolsky et al. (2007).

\section{A2 Carbon model description}

A satellite-based light use efficiency (LUE) approach was used to estimate vegetation productivity:

$\mathrm{GPP}=\varepsilon \times \mathrm{FPAR} \times \mathrm{PAR}$

where GPP is the gross primary productivity $\left(\mathrm{g} \mathrm{C} \mathrm{m}^{-2} \mathrm{~d}^{-1}\right)$; $\varepsilon\left(\mathrm{g} \mathrm{CMJ}^{-1}\right)$ is the LUE coefficient converting absorbed photosynthetically active solar radiation (APAR) to vegetation biomass, and FPAR defines the fraction of incident PAR (MJ m $\left.{ }^{-2} \mathrm{~d}^{-1}\right)$ absorbed by the vegetation canopy (i.e., APAR). A maximum LUE coefficient $\left(\varepsilon_{\max }, \mathrm{g} \mathrm{C} \mathrm{MJ}^{-1}\right)$ was prescribed for each land cover type and was reduced for suboptimal environmental conditions (including low air temperature, soil moisture and frozen conditions) to estimate $\varepsilon$ (Yi et al., 2013). Vegetation net primary productivity (NPP) was estimated as a fixed portion of GPP for each biome type based on an assumption of conservatism in vegetation carbon use efficiency within similar plant functional types.

A dynamic carbon allocation of litterfall estimated from NPP, based on Randerson et al. (1996) and White et al. (2000), was used to characterize litterfall seasonality. The total litterfall was partitioned into three components, including leaves, fine roots, and woody components with prescribed ratios for each plant functional type based on field experiments (White et al., 2000; Table S2). Daily constant turnover rates were prescribed for the woody components of litterfall including stems and coarse roots (White et al., 2000), while the NDVI time series were used to characterize turnover rates of the other two variable components of litterfall during leaf senescence and active growth periods (Randerson et al., 1996). Approximately half of the fine root turnover was assumed to occur during the active growing season, and the monthly variable fraction of litterfall was calcu- 
lated as

$$
\begin{aligned}
& \operatorname{LT}_{\mathrm{var} 1}(t)=\frac{\mathrm{LL}(t)}{\sum_{t=1}^{12} \mathrm{LL}(t)} \cdot\left(\mathrm{LT}_{\text {leaf }}+\mathrm{LT}_{\text {froot }} \cdot 0.5\right), \\
& \mathrm{LT}_{\mathrm{var} 2}(t)=\frac{\operatorname{NDVI}(t)}{\sum_{t=1}^{12} \mathrm{NDVI}(t)} \cdot \mathrm{LT}_{\text {froot }} \cdot 0.5 \\
& \mathrm{LL}(t)=[0.5 \cdot \mathrm{NDVI}(t-2)+\mathrm{NDVI}(t-1)] \\
& -[\operatorname{NDVI}(t+1)+0.5 \cdot \operatorname{NDVI}(t+2)]
\end{aligned}
$$

where $\operatorname{LT}_{\text {var1 }}(t)$ and $\operatorname{LT}_{\mathrm{var} 2}(t)$ represent the litterfall fraction associated with leaf loss (i.e., $\operatorname{LL}(t)$ ) and vegetation active growth, respectively; $\mathrm{LT}_{\text {leaf }}$ and $\mathrm{LT}_{\text {froot }}$ are the prescribed fractions of leaf and fine-root components for each plant functional type, respectively (Table S2). The estimated monthly litterfall fraction was then distributed evenly over the month.

To account for the contribution of deep soil organic carbon pools to the total heterotrophic respiration $\left(R_{\mathrm{h}}\right)$, we extended the original terrestrial carbon flux (TCF) soil decomposition model to incorporate soil organic carbon down to $3 \mathrm{~m}$ below the surface, and multiple litter and soil organic carbon (SOC) pools were used to characterize the progressive decomposition of fresh litter to more recalcitrant materials. Following Biome-BGC (BioGeochemical Cycles; Thornton et al., 2002), the new soil decomposition model includes three litterfall pools, 3 SOC pools with relatively fast turnover rates and a deep SOC pool with slow turnover rates (Fig. S1). The litterfall carbon inputs were first allocated to the three litterfall pools according to the substrate quality of each litterfall component, i.e., labile, cellulose and lignin fractions of estimated leaf, fine root, and woody litterfall (Table S3; White et al., 2000), and then transferred to the SOC pools through progressive decomposition.
For each carbon pool $\left(C_{i}\right)$, the carbon balance of the decomposition process was defined as

$\frac{\partial C_{i}}{\partial t}=R_{i}+\sum_{j \neq i}\left(1-r_{j}\right) T_{j i} k_{j} C_{j}-k_{i} C_{i}$,

where $R_{i}$ is the carbon input from litterfall allocated to pool $i$ (only nonzero for the 3 litterfall pools), $T_{j i}$ is the fraction of carbon directed from pool $j$ to pool $i$ with fraction $r_{j}$ lost as respiration, and $k_{i}\left(k_{j}\right)$ is the decomposition rate of carbon pool $i(j)$. The heterotrophic respiration $\left(R_{\mathrm{h}}\right)$ is then computed as the sum of respiration fluxes from the decomposition process:

$R_{\mathrm{h}}=\sum_{i=1,7} r_{i} k_{i} C_{i}$

The soil decomposition rate $\left(k_{i}\right)$ for each pool is derived as the product of a theoretical maximum rate constant $\left(k_{\max , i}\right.$, Fig. S1) and dimensionless multipliers for soil temperature $\left(T_{\text {mult }}\right)$ and moisture $\left(W_{\text {mult }}\right)$ constraints to decomposition under prevailing climate conditions:

$k_{i}=k_{\max , i} \cdot T_{\text {mult }} \cdot W_{\text {mult }}$,

where $T_{\text {mult }}$ and $W_{\text {mult }}$ vary between 0 (fully constrained) and 1 (no constraint), as defined in Yi et al. (2013). 


\section{The Supplement related to this article is available online at doi:10.5194/bg-12-5811-2015-supplement.}

Acknowledgements. This work was supported with funding from the NASA Interdisciplinary Research in Earth Science program. Data from the Imnavait tundra tower measurement was collected through a grant from the National Science Foundation Office of Polar Programs, Arctic Observatory Network. We thank M. Goulden for providing boreal forest tower measurements in Manitoba, Canada.

Edited by: M. Bahn

\section{References}

Baldocchi, D.: Breathing of the terrestrial biosphere: lessons learned from a global network of carbon dioxide flux measurement systems, Aust. J. Bot., 56, 1-26, 2008.

Bi, J., Xu, L., Samanta, A., Zhu, Z., and Myneni, R.: Divergent Arctic-Boreal Vegetation Changes between North America and Eurasia over the Past 30 Years, Remote Sensing, 5, 2093-2112, 2013.

Brown, J., Hinkel, K. M., and Nelson, F. E.: The circumpolar active layer monitoring (CALM) program: Research designs and initial results, Polar Geography, 24, 166-258, 2000.

Brown, R. D. and Robinson, D. A.: Northern Hemisphere spring snow cover variability and change over 1922-2010 including an assessment of uncertainty, The Cryosphere, 5, 219-229, doi:10.5194/tc-5-219-2011, 2011.

Dyer, J. L. and Mote, T. L.: Spatial variability and trends in observed snow depth over North America, Geophys. Res. Lett., 33, L16503, doi:10.1029/2006GL027258, 2006.

Entekhabi, D., Njoku, E. G., O’Neill, P. E., Kellogg, K. H., Crow, W. T., Edelstein, W. N., Entin, J. K., Goodman, S. D., Jackson, T. J., Johnson, J., Kimball, J., Piepmeier, J. R., Koster, R. D., Martin, N., McDonald, K. C., Moghaddam, M., Moran, S., Reichle, R., Shi, J. C., Spencer, M. W., Thurman, S. W., Tsang, L., and Van Zyl, J.: The Soil Moisture Active Passive (SMAP) Mission, P. IEEE, 98, 704-716, 2010.

Euskirchen, E. S., McGuire, A. D., and Chapin, F. S.: Energy feedbacks of northern high-latitude ecosystems to the climate system due to reduced snow cover during 20th century warming, Glob. Change Biol., 13, 2425-2438, 2007.

Euskirchen, E. S., Bret-Harte, M. S., Scott, G. J., Edgar, C., and Shaver, G. R.: Seasonal patterns of carbon dioxide and water fluxes in three representative tundra ecosystems in northern Alaska, Ecosphere, 3, 4, doi:10.1890/es11-00202.1, 2012.

Friedl, M. A., Sulla-Menashe, D., Tan, B., Schneider, A., Ramankutty, N., Sibley, A., and Huang, X.: MODIS Collection 5 global land cover: Algorithm refinements and characterization of new datasets, Remote Sens. Environ., 114, 168-182, 2010.

Global Soil Data Task: Global Soil Data Products CD-ROM (IGBP-DIS), CD-ROM, International Geosphere-Biosphere Programme, Data and Information System, Potsdam, Germany, Oak Ridge National Laboratory Distributed Active Archive Center, Oak Ridge, Tennessee, USA, 2000.
Goulden, M. L., McMillan, A. M. S., Winston, G. C., Rocha, A. V., Manies, K. L., Harden, J. W., and Bond-Lamberty, B. P.: Patterns of NPP, GPP, respiration, and NEP during boreal forest succession, Glob. Change Biol., 17, 855-871, 2011.

Gouttevin, I., Menegoz, M., Domine, F., Krinner, G., Koven, C., Ciais, P., Tarnocai, C., and Boike, J.: How the insulating properties of snow affect soil carbon distribution in the continental pan-Arctic area, J. Geophys. Res., 117, 117, G02020, doi:10.1029/2011JG001916, 2012.

Grosse, G., Harden, J., Turetsky, M., McGuire, A. D., Camill, P., Tarnocai, C., Frolking, S., Schuur, E. A. G., Jorgenson, T., Marchenko, S., Romanovsky, V., Wickland, K. P., French, N., Waldrop, M., Bourgeau-Chavez, L., and Striegl, R. G.: Vulnerability of high-latitude soil organic carbon in North America to disturbance, J. Geophys. Res., 116, G00K06, doi:10.1029/2010JG001507, 2011.

Harden, J. W., Manies, K. L., Turetsky, M. R., and Neff, J. C.: Effects of wildfire and permafrost on soil organic matter and soil climate in interior Alaska, Glob. Change Biol., 12, 2391-2403, 2006.

Hobbie, S. E., Schimel, J. P., Trumbore, S. E., and Randerson, J. R.: Controls over carbon storage and turnover in high-latitude soils, Glob. Change Biol., 6, 196-210, 2000.

Hugelius, G., Strauss, J., Zubrzycki, S., Harden, J. W., Schuur, E. A. G., Ping, C.-L., Schirrmeister, L., Grosse, G., Michaelson, G. J., Koven, C. D., O’Donnell, J. A., Elberling, B., Mishra, U., Camill, P., Yu, Z., Palmtag, J., and Kuhry, P.: Estimated stocks of circumpolar permafrost carbon with quantified uncertainty ranges and identified data gaps, Biogeosciences, 11, 6573-6593, doi:10.5194/bg-11-6573-2014, 2014.

Jorgenson, M. T., Shur, Y. L., and Pullman, E. R.: Abrupt increase in permafrost degradation in Arctic Alaska, Geophys. Res. Lett., 33, L02503, doi:10.1029/2005GL024960, 2006.

Kim, Y., Kimball, J. S., Zhang, K., and McDonald, K. C.: Satellite detection of increasing Northern Hemisphere non-frozen seasons from 1979 to 2008: Implications for regional vegetation growth, Remote Sens. Environ., 121, 472-487, 2012.

Kim, Y., Kimball, J. S., Robinson, D. A., and Derksen, C.: New satellite climate data records indicate strong coupling between recent frozen season changes and snow cover over high northern latitudes, Environ. Res. Lett., 10, 084004, doi:10.1088/17489326/10/8/084004, 2015.

Kimball, J. S., Jones, L. A., Zhang, K., Heinsch, F. A., McDonald, K. C., and Oechel, W. C.: A Satellite Approach to Estimate LandAtmosphere $\mathrm{CO}_{2}$ Exchange for Boreal and Arctic Biomes Using MODIS and AMSR-E, IEEE T. Geosci. Remote, 47, 569-587, 2009.

Koven, C. D., Ringeval, B., Friedlingstein, P., Ciais, P., Cadule, P., Khvorostyanov, D., Krinner, G., and Tarnocai, C.: Permafrost carbon-climate feedbacks accelerate global warming, P. Natl. Acad. Sci. USA, 108, 14769-14774, 2011.

Koven, C. D., Lawrence, D. M., and Riley, W. J.: Permafrost carbon-climate feedback is sensitive to deep soil carbon decomposability but not deep soil nitrogen dynamics, P. Natl. Acad. Sci. USA, 112, 3752-3757, doi:10.1073/pnas.1415123112, 2015.

Jafarov, E. E., Romanovsky, V. E., Genet, H., McGuire, A. D., and Marchenko, S. S.: The effects of fire on the thermal stability of permafrost in lowland and upland black spruce forests of inte- 
rior Alaska in a changing climate, Environ. Res. Lett., 8, 035030, doi:10.1088/1748-9326/8/3/035030, 2013.

Lawrence, D. M. and Slater, A. G.: Incorporating organic soil into a global climate model, Clim. Dynam., 30, 145-160, 2008.

Lawrence, D. M. and Slater, A. G.: The contribution of snow condition trends to future ground climate, Clim. Dynam., 34, 969-981, 2010.

Liston, G. E., Haehnel, R. B., Sturm, M., Hiemstra, C. A., Berezovskaya, S., and Tabler, R. D.: Instruments and methods simulating complex snow distributions in windy environments using SnowTran-3D, J. Glaciol., 53, 241-256, 2007.

Lüers, J., Westermann, S., Piel, K., and Boike, J.: Annual $\mathrm{CO}_{2}$ budget and seasonal $\mathrm{CO}_{2}$ exchange signals at a high Arctic permafrost site on Spitsbergen, Svalbard archipelago, Biogeosciences, 11, 6307-6322, doi:10.5194/bg-11-6307-2014, 2014.

Mishra, U. and Riley, W. J.: Active-Layer Thickness across Alaska: Comparing Observation-Based Estimates with CMIP5 Earth System Model Predictions, Soil Sci. Soc. Am. J., 78, 894-902, doi:10.2136/sssaj2013.11.0484, 2014.

Monson, R. K., Lipson, D. L., Burns, S. P., Turnipseed, A. A., Delany, A. C., Williams, M. W., and Schmidt, S. K.: Winter forest soil respiration controlled by climate and microbial community composition, Nature, 439, 711-714, 2006.

Nicolsky, D. J., Romanovsky, V. E., Alexeev, V. A., and Lawrence, D. M.: Improved modeling of permafrost dynamics in a GCM land-surface scheme, Geophys. Res. Lett., 34, L08501, doi:10.1029/2007GL029525, 2007.

Nowinski, N. S., Taneva, L., Trumbore, S. E., and Welker, J. M.: Decomposition of old organic matter as a result of deeper active layers in a snow depth manipulation experiment, Oecologia, 163, 785-792, 2010.

Osterkamp, T. E.: Characteristics of the recent warming of permafrost in Alaska, J. Geophys. Res.-Earth, 112, F02S02, doi:10.1029/2006JF000578, 2007.

Park, H., Sherstiukov, A. B., Fedorov, A. N., Polyakov, I. V., and Walsh, J. E.: An observation based assessment of the influences of air temperature and snow depth on soil temperature in Russia, Environ. Res. Lett., 9, 064026, doi:10.1088/17489326/9/6/064026, 2014.

Randerson, J. T., Thompson, M. V., Malmstrom, C. M., Field, C. B., and Fung, I. Y.: Substrate limitations for heterotrophs: Implications for models that estimate the seasonal cycle of atmospheric $\mathrm{CO}_{2}$, Global Biogeochem. Cy., 10, 585-602, 1996.

Rawlins, M. A., Lammers, R. B., Frolking, S., Fekete, B. z. M., and Vorosmarty, C. J.: Simulating pan-Arctic runoff with a macroscale terrestrial water balance model, Hydrol. Process., 17, $2521-$ 2539, 2003.

Rawlins, M. A., Nicolsky, D. J., McDonald, K. C., and Romanovsky, V. E.: Simulating soil freeze/thaw dynamics with an improved pan-Arctic water balance model, Journal of Advances in Modeling Earth Systems, 5, 659-675, 2013.

Romanovsky, V. E. and Osterkamp, T. E.: Effects of unfrozen water on heat and mass transport processes in the active layer and permafrost, Permafrost. Periglac., 11, 219-239, 2000.

Romanovsky, V. E., Drozdov, D. S., Oberman, N. G., Malkova, G. V., Kholodov, A. L., Marchenko, S. S., Moskalenko, N. G., Sergeev, D. O., Ukraintseva, N. G., Abramov, A. A., Gilichinsky, D. A., and Vasiliev, A. A.: Thermal state of permafrost in Russia, Permafrost. Periglac., 21, 136-155, 2010a.
Romanovsky, V. E., Smith, S. L., and Christiansen, H. H.: Permafrost thermal state in the polar Northern Hemisphere during the international polar year 2007-2009: a synthesis, Permafrost. Periglac., 21, 106-116, 2010 b.

Schaefer, K., Zhang, T. J., Slater, A. G., Lu, L. X., Etringer, A., and Baker, I.: Improving simulated soil temperatures and soil freeze/thaw at high-latitude regions in the Simple Biosphere/Carnegie-Ames-Stanford Approach model, J. Geophys. Res.-Earth, 114, F02021, doi:10.1029/2008JF001125, 2009.

Schaefer, K., Zhang, T. J., Bruhwiler, L., and Barrett, A. P.: Amount and timing of permafrost carbon release in response to climate warming, Tellus Series B, 63, 165-180, 2011.

Schimel, J. P., Bilbrough, C., and Welker, J. A.: Increased snow depth affects microbial activity and nitrogen mineralization in two Arctic tundra communities, Soil Biol. Biochem., 36, 217227, 2004.

Schuur, E. A. G., Crummer, K. G., Vogel, J. G., and Mack, M. C.: Plant species composition and productivity following permafrost thaw and thermokarst in alaskan tundra, Ecosystems, 10, 280 292, 2007.

Schuur, E. A. G., McGuire, A. D., Schädel, C., Grosse, G., Harden, J. W., Hayes, D. J., Hugelius, G., Koven, C. D., Kuhry, P., Lawrence, D. M., Natali, S. M., Olefeldt, D., Romanovsky, V. E., Schaefer, K., Turetsky, M. R., Treat, C. C., and Vonk, J. E.: Climate change and the permafrost carbon feedback, Nature, 520, 171-179, 2015.

Serreze, M. C. and Francis, J. A.: The arctic amplification debate, Climatic Change, 76, 241-264, 2006.

Smith, L. C., Sheng, Y., MacDonald, G. M., and Hinzman, L. D.: Disappearing Arctic lakes, Science, 308, 1429-1429, 2005.

Solomon, S.: Intergovernmental Panel on Climate Change, and Intergovernmental Panel on Climate Change, Working Group I.: Climate change 2007: the physical science basis: contribution of Working Group I to the Fourth Assessment Report of the Intergovernmental Panel on Climate Change, Cambridge University Press, Cambridge, New York, 2007.

Stieglitz, M.: The role of snow cover in the warming of arctic permafrost, Geophys. Res. Lett., 30, 1721, doi:10.1029/2003GL017337, 2003.

Sturm, M., Holmgren, J., Konig, M., and Morris, K.: The thermal conductivity of seasonal snow, J. Glaciol., 43, 26-41, 1997.

Sturm, M., Schimel, J., Michaelson, G., Welker, J. M., Oberbauer, S. F., Liston, G. E., Fahnestock, J., and Romanovsky, V. E.: Winter biological processes could help convert arctic tundra to shrubland, BioScience, 55, 17-26, 2005.

Sullivan, P. F.: Snow distribution, soil temperature and late winter $\mathrm{CO}_{2}$ efflux from soils near the Arctic treeline in northwest Alaska, Biogeochemistry, 99, 65-77, 2010.

Tabatabaeenejad, A., Burgin, M., Duan, X. Y., and Moghaddam, M.: P-Band Radar Retrieval of Subsurface Soil Moisture Profile as a Second-Order Polynomial: First AirMOSS Results, IEEE T. Geosci. Remote., 53, 645-658, 2015.

Tape, K., Sturm, M., and Racine, C.: The evidence for shrub expansion in Northern Alaska and the Pan-Arctic, Glob. Change Biol., 12, 686-702, 2006.

Thornton, P. E., Law, B. E., Gholz, H. L., Clark, K. L., Falge, E., Ellsworth, D. S., Golstein, A. H., Monson, R. K., Hollinger, D., Falk, M., Chen, J., and Sparks, J. P.: Modeling and measuring the 
effects of disturbance history and climate on carbon and water budgets in evergreen needleleaf forests, Agr. Forest Meteorol., 113, 185-222, 2002.

Waldrop, M. P., Wickland, K. P., White III, R., Berhe, A. A., Harden, J. W. and Romanovsky, V. E.: Molecular investigations into a globally important carbon pool: permafrost-protected carbon in Alaskan soils, Glob. Change Biol., 16, 2543-2554, doi:10.1111/j.1365-2486.2009.02141.x, 2010.

Walker, D. A., Raynolds, M. K., Daniels, F. J. A., Einarsson, E., Elvebakk, A., Gould, W. A., Katenin, A. E., Kholod, S. S., Markon, C. J., Melnikov, E. S., Moskalenko, N. G., Talbot, S. S., Yurtsev, B. A., and Team, C.: The Circumpolar Arctic vegetation map, J. Veg. Sci., 16, 267-282, 2005.

Watts, J. D., Kimball, J. S., Jones, L. A., Schroeder, R., and McDonald, K. C.: Satellite Microwave remote sensing of contrasting surface water inundation changes within the Arctic-Boreal Region, Remote Sens. Environ., 127, 223-236, 2012.

Weedon, G. P., Balsamo, G., Bellouin, N., Gomes, S., Best, M. J., and Viterbo, P.: The WFDEI meteorological forcing data set: WATCH Forcing Data methodology applied to ERA-Interim reanalysis data, Water Resour. Res., 50, 7505-7514, 2014.

White, M. A., Thornton, P. E., Running, S. W., and Nemani, R. R.: Parameterization and Sensitivity Analysis of the BIOME-BGC Terrestrial Ecosystem Model: Net Primary Production Controls, Earth Interact., 4, 1-85, 2000.

Xu, L., Myneni, R. B., Chapin III, F. S., Callaghan, T. V., Pinzon, J. E., Tucker, C. J., Zhu, Z., Bi, J., Ciais, P., Tømmervik, H., Euskirchen, E. S., Forbes, B. C., Piao, S. L., Anderson, B. T., Ganguly, S., Nemani, R. R., Goetz, S. J., Beck, P. S. A., Bunn, A. G., Cao, C., and Stroeve, J. C.: Temperature and vegetation seasonality diminishment over northern lands, Nature Climate Change, 3, 581-586, doi:10.1038/nclimate1836, 2013.
Yi, Y., Kimball, J. S., Jones, L. A., Reichle, R. H., Nemani, R., and Margolis, H. A.: Recent climate and fire disturbance impacts on boreal and arctic ecosystem productivity estimated using a satellite-based terrestrial carbon flux model, J. Geophys. Res.Biogeo., 118, 606-622, 2013.

Yi, Y., Kimball, J. S., and Reichle, R. H.: Spring hydrology determines summer net carbon uptake in northern ecosystems, Environ. Res. Lett., 9, 064003, doi:10.1088/1748-9326/9/6/064003, 2014.

Zhang, T.: Influence of the seasonal snow cover on the ground thermal regime: an overview, Rev. Geophys., 43, RG4002, doi:10.1029/2004RG000157, 2005.

Zhang, T., Heginbottom, J. A., Barry, R. G., and Brown, J.: Further statistics on the distribution of permafrost and ground ice in the northern hemisphere, Polar Geography, 24, 126-131, 2000.

Zhang, T., Frauenfeld, O. W., Serreze, M. C., Etringer, A., Oelke, C., McCreight, J., Barry, R. G., Gilichinsky, D., Yang, D. Q. Ye, H. C., Ling, F., and Chudinova, S.: Spatial and temporal variability in active layer thickness over the Russian Arctic drainage basin, J. Geophys. Res.-Atmos., 110, D16101, doi:10.1029/2004JD005642, 2005.

Zimov, S. A., Davidov, S. P., Voropaev, Y. V., Prosiannikov, S. F., Semiletov, I. P., Chapin, M. C., and Chapin, F. S.: Siberian $\mathrm{CO}_{2}$ efflux in winter as a $\mathrm{CO}_{2}$ source and cause of seasonality in atmospheric $\mathrm{CO}_{2}$, Climatic Change, 33, 111-120, 1996. 